\title{
PLATE TECTONICS AND EARTH EVOLUTION: A CONCEPTUAL REVIEW
}

\author{
Pilchin A.N. ${ }^{1}$, Eppelbaum L.V. ${ }^{2,3}$ \\ ${ }^{1}$ Universal Geoscience and Environment Consulting Company, \\ 205 Hilda Ave., Willowdale, Ontario, Canada M2M 4B1 \\ ${ }^{2}$ Department of Earth Sciences, Faculty of Exact Sciences, Tel Aviv University, \\ Ramat Aviv 6997801, Tel Aviv, Israel \\ ${ }^{3}$ Azerbaijan State Oil and Industry University, \\ 20 Azadlig Ave., Baku AZ1010, Azerbaijan
}

Keywords: plate tectonic processes, main forces, thermodynamic models, role of density, models of deep structure, early Earth evolution
Summary. Numerous attempts have been made to understand the rules of Earth's tectonogeodynamic processes over the past centuries. While no paradigm has offered comprehensive answers to all of the questions, the present review aims to acquaint readers with the modern state of developments in the tectonic insights of Earth's evolution. A number of very interesting and unique processes and features took place during the evolution of early Earth. Most of these, however, were largely erased over the course of Earth's ensuing evolution; some leaving only traces of their existence and remnant phenomena, especially those taking place in the Hadean and Early to Late Archean. Among such processes and features are: the planetary accretion of Earth, formation of unique rock complexes, initiation of the plate tectonics phenomenon, main forces driving plate tectonics, significant influence of thermal parameters, role of overpressure under different physicalgeological environments, stratification of Earth's crust and lithosphere by density, and various other thermodynamic models. Nearly all of these remain enigmatic, due to considerable uncertainty in the timing and method of their evolution, and the ambiguity of their secondary processes and tectono- geophysical indicators. At the same time, these tectono-geodynamic processes and features are also interrelated, and the simultaneous fluctuation of myriad different factors plays a significant role in their formation. Some of these intricate questions are discussed in this paper. What is the role of the plate tectonics phenomenon and when did this process initiate on Earth? Especial attention is paid in the review to the sophisticated historical methods of understanding tectonic processes over the course of various generations of geoscientists. In the conducted analyses, certain physical data derived from other planets of the Solar System were utilized as well.

(C) 2020 Earth Science Division, Azerbaijan National Academy of Sciences. All rights reserved.

\section{Introduction}

It is evident that solidification of the magmaocean and formation of the lithosphere were among the first steps necessary to initiate different tectonic processes on Earth (e.g., Pilchin and Eppelbaum, 2009). It is then essential to understand which tectonic processes operated during early Earth evolution. At a time with only partial solidification of the magma-ocean, any formed (or partly formed) solid blocks could undertake strictly vertical movements, as dictated by Newton's law of gravity and Archimedes' law of buoyancy. However, it would be premature to account such movements of solid blocks floating within the magma-ocean as tectonic processes. Only as the magma-ocean solidified, with the formation and thickening of the early lith- osphere tectonic processes could finally commence. It is important to determine what types of tectonic processes were operational at the time: Were they caused mostly by vertical (isostatic) movements (one of the fixist models) or horizontal (one of the mobilistic models)? There are myriad differences between these two groups of models. Fixist models (e.g., contraction theory, theory of isostasy, gravitational differentiation, expanding Earth, pulsating Earth, geosynclinal theory, rifting, and diapir model) postulate an unchanged position of continents over the asthenosphere, emphasizing vertical movements and not permitting horizontal displacement by greater than tens of kilometers. In contrast, mobilist models (e.g., continental drift, seafloor spreading, plate tectonics) postulate im- 
mense (hundreds and thousands of kilometers) horizontal displacements of the lithosphere (including continents) over the asthenosphere, with subordinate vertical displacements.

The known fixist models explain tectonic evolution as a consecutive change of stages: pregeosynclinal (formation of oceanic crust; basaltic layer); geosynclinal (formation of continental crust; granitic-metamorphic layer); and platform (transition from active regimes to quiet and stable ones) (e.g., Gnibidenko and Shashkin, 1970; Хаин, 1973; Белоусов, 1975). The geosynclinal theory stood as the primary tectonic methodology for over a hundred years (е.g., Хаин, Шейнман, 1960), before most scientists adopted the plate tectonics theory as the main tectonic model of Earth evolution. In recent times some scientists (for instance, private communications with V.E.Khain in 2010) consider it obsolete.

The geosyncline theory, the most comprehensive of the fixist models, was first introduced by

J.Hall in his meeting report in 1857 (Knopf, 1960, Knopoff, 1964) and his subsequent publication (Hall, 1859), to be further elaborated by Dana (Dana, 1873; Knopf, 1960, Knopoff, 1964). Additional improvements on this theory are attributed to such scientists as Daly (1912), Kober (1921), Stille (1924, 1940, 1944) and many others (Knopf, 1960, Knopoff, 1964). This theory helped explain many tectonic processes taking place on continents, but from the onset of the second half of the 20th century, a growing number of geological and geophysical data for oceanic regions raised new problems that it could not explain. This led to the introduction of a new model in a number of publications at the end of the 1960s and 1970s, plate tectonics, which took the geosynclinal theory's place as the foundational geotectonic model.

The following is under question: can the fixist models be used to explain the tectonic regime in the Hadean - Early Archean. We beleive that the answer is 'yes' - some fixist models can be applied to illustrate the tectonic evolution in the Hadean - Early Archean. This period of Earth's evolution was characterized by a regime of cooling (solidification of the magma-ocean, and formation and cooling of the lithosphere), which means that the contracting Earth theory (e.g., Алейников и др., 2001; Stacey and Davis, 2008) can at least partially be applied to tectonic evolution. At the same time during most of the Hadean - Early Archean, the upper mantle was hot and the asthenosphere likely not yet completely solidified. Logically, the early lithosphere would then have been floating atop the remnants of the magmaocean in the cooling mantle, and the lithospheric temperature would have been comparatively high, with surface temperatures dropping to $500-600 \mathrm{~K}$ only at the very end of the Early Archean (Pilchin, 2011; Pilchin and Eppelbaum, 2012; Eppelbaum et al., 2014). This would mean that the lithosphere was likely dictated by vertical forces, which could be explained by the isostatic theory (Anderson, 2007; Stacey and Davis, 2008). However the geosynclinal theory could not be applied to tectonic evolution in the Hadean - Early Archean, even though regions of the early Earth were represented by ancient shields that were not tectonically active. The reason for this is the fact that the water-ocean only emerged at 3.42-3.26 Ga, at the end of the Early Archean (Pilchin and Eppelbaum, 2012; Eppelbaum et al., 2014), which eliminates the possibility of oceanic crust formation (pre-geosynclinal stage) prior to that time. Moreover, the geosynclinal stage requires the collection of a thick sedimentary layer, while no significant amounts of sedimentary deposits are known in the Hadean and Early Archean before the start of the formation of Moodies Group, Barberton GSB, South Africa at about 3.26-3.259 Ga (Eppelbaum et al., 2014). This means that the geosyncline theory cannot be used for analysis of possible tectonic processes during early Earth evolution.

The plate tectonics theory is accepted at present by the absolute majority of geoscientists, it is important to analyze the geological-geophysical facts (evidence) which may help facilitate further evaluation of this theory.

\section{What is the plate tectonics model?}

Before delving into the plate tectonics model, let us briefly discuss what modeling means in science, and in geology in particular. Scientific modeling is the generation of a physical, conceptual or mathematical representation of a real phenomenon that is difficult to observe directly (Roger, 2015). While over the past decades modeling has become a powerful method of research, scientific models remain approximations of the objects and systems they represent, rather than their exact replicas (Roger, 2015). The aim of scientific modeling is to visualize certain events and processes for easier learning and better understanding. The purpose of modeling is generating new knowledge about the objects in question (Schwarz et al., 2009). Various (sometimes specific) types of modeling are utilized in different scientific disciplines (e.g., Cartwright, 1983; Hacking, 1983). A scientific model is usually based on certain empirical facts and observations related to events, phenomena and physical processes reflecting or representing the reality as closely as possible. A good model should focus on the key features to explain and predict the scientific phenomena (Schwarz et al., 2009). The main criteria for a model are: the ability 
to explain past observations better than other models, revealing new knowledge about the object of modeling, and making predictions for future observations (actual testing of the model). Models that are employed should be perpetually re- evaluated and revised (e.g., Schwarz et al., 2009). Geologic modeling (geomodeling) is usually related to representations of different parts of the Earth (layers, regions, areas, structures, blocks, slabs, domains, objects) based on geological and geophysical data and observations (it could be computerized, 1D, 2D or 3D) (e.g., Mallet, 2008).

One of the most complete reviews on the problems of modeling, collecting data and data interpretation (analysis) in geology is given by Naimark (Наймарк, 2006) on the basis of discussions between followers of the fixist and mobilist models in geotectonics. He states that one of the most urgent problems in geoscience is the correct modeling of different intricate geologic features and processes. Naimark (2006) asserts that since none of the models (fixist, mobilist, or any other concept) encapsulate our physical-geological reality, by definition they can neither entirely describe our reality, nor entirely disprove our understanding of it. He indicates that there are no clear facts that uniquely speak for themselves without the necessity for interpretation, which always relies on certain methodologies. This makes any modeling fundamentally subjective, because any model is developed by a researcher whose views on different matters could be vastly different from those of others. However, any real object could be represented by multiple different models in a fashion that is not arbitrary, but reflects real facts and observations. Interestingly, one of the authors of this paper previously realized this idea in exploration geophysics (Эппельбаум, 1987), where he suggested the application of a multi-model approach to these same subjects under study.

The notion of objectivity in geoscience means that something is independent of our individual awareness of reality (Абрамович, 1978). Ivin (Ивин, 1986) states that any fact exists within the framework of a certain theoretical construction, and is therefore always theoretically loaded; that behind any fact there is always some reasoning. Frolov (Фролов, 2002) believes that objectively collected and correctly summarized facts will lead to a correct interpretation on their own. Yet we must ask: where does such criteria and correct summarizing of facts come from? Researchers themselves develop these over a framework of their experience, where they employ certain theoretical views (Наймарк, 2006). Verhoogen et al. (1970) also point out that while field observations are an important source of information in geology, they could only be fully inter- preted by analytical methods. Naimark (Наймарк, 2006) notes that if any particular concept at present solves a great number of fundamental problems more effectively than alternative concepts, then it is a better reflection of reality than the others. Based on such inquiry, Naimark (Наймарк, 2006) came to the following conclusions:

(1) the direct purpose of a model is not reflecting reality absolutely fully and exactly (as that is impossible), but to be convenient for solving certain important problems effectively; (2) preference of specific scientific concept is justified only to the extent in which it is effective for the explanations, reconstructions and predictions of natural processes; (3) a model should include only those properties and relations that are necessary for solving a specific problem; and (4) the main purpose of any research is not to search for truth as such, but the development of models of reality based on which it would be possible to solve problems more effectively.

Unfortunately, many geologists believe that geology is too complex to follow the classical laws of physics (e.g., Thomas, 1932; Wilson, 1990), with some scientists going so far as to outright challenge physical laws as contradictory to geological processes (e.g., Petrini and Podladchikov, 2000; Dunlop, 2009). With respect to this, it should be stated that regardless of the given model chosen by a researcher in geology, the model still necessarily includes rocks and/or rock complexes. Rock complexes are characterized by their: position within geologic structures; dimensions (length, width, height); volume; incidence angle (slope angle); contacts with other rock complexes, water bodies, and/or atmosphere; and other properties. Certain rock complexes have categorical rock compositions, and each rock has certain mineral compositions. In turn, every mineral has a certain chemical composition, which is characterized by physical and chemical properties. There are characteristic features among the physical properties of any mineral: density, melting point, liquidus and solidus temperatures, hardness, volume thermal expansion, compressibility, tensile, shear and compressive strength limits, conditions of stability at temperature and pressure, and others. Among the most important chemical properties of any mineral are: reaction with oxygen; reaction with water; reaction with aggressive fluids formed within the Earth layers; transformations between rocks and minerals under certain conditions (e.g., transformation of ferrous iron oxides to ferric iron oxides, transformation of basalt to eclogite, metamorphic processes, and many others), and certain others. Whether or not all of these properties are discussed in a geological (geophysical) model, they are nevertheless always in effect and will always play a role under certain condi- 
tions. Any geologic process is dictated by certain physical and chemical properties, and it is wrong to say geology does not follow the proven laws of physics.

The plate tectonics model is based on two previous mobilist models: (a) Mantle convection, and (b) Seafloor spreading (or continental drift). Convection is a key component in the plate tectonics model, as seafloor spreading also depends on mantle convection.

Hopkins $(1839,1847)$ was the first to use mathematical analysis and mechanical principles to propose the possibility of convection below Earth's crust (Davies, 1999; Glen, 2005), even though he believed the solid crust was hundreds of miles thick. Fisher $(1878,1881)$ discussed a thin fluid layer just below the crust in the Earth's interior, proposing mantle convection as a tectonic agent, with flow rising beneath the oceans and descending under continents to explain mountain building (Davies, 1999; Glen, 2005). Ampferer (1906) was the first to introduce the hypothesis of understreaming currents in the mantle as the driving force for mountain building. He postulated that compression forces and the formation of nappes were generated by mass currents beneath mountain ranges. Ampferer (1906) also proposed the existence of downwelling mantle convection currents (Unterstromungen) causing orogenic folding and shearing. Joly (1909) offered an explanation to Ampferer's ideas, suggesting that radiogenic heat cyclically melted and solidified the subcrust to produce convection. Schwinner (1915, 1919) used Ampferer's ideas to develop a theory stating that convective heat transport produces currents in the Earth's interior. He modeled convection currents in a tectonosphere as crustal plates positioned atop convecting flows. Lord Rayleigh (1916) offered a correct theoretical interpretation of Bénard's $(1900,1901)$ experiments using thin liquid layers. The idea of mantle convection was introduced by Bull (1921) to explain continental drift (Herndon, 2010). Jeffreys (1927) came to the conclusion that the viscosity of the mantle would not disallow convection. Based on the above ideas, Holmes (1928a,b, 1929, 1930, 1931) introduced the model of a convection engine for seafloor spreading, which is generally implemented in the present plate tectonics model. His model is described in greater detail in Holmes (1944).

Theories related to the movement of continents were offered by a number of researchers starting from the 16th century (Romm, 1994). Ortelius (1596) was the first to propose the basic elements of the continental drift theory. Among other researchers to offer such theories, the following should be mentioned here: von Humboldt (1801), who can be con- sidered one of the founders of Geothermics (Eppelbaum et al., 2014), proposed that the lands bordering the Atlantic Ocean had once been joined together (see Schmeling, 2004); and later Antonio Snider-Pellegrini (1859) proposed that the Americas were at one time connected to Europe and Africa. These problems were also discussed by Taylor in 1908 (as described in: Leviton et al., 1985 and Frank B. Taylor, 2015) and in Taylor (1910), who linked the formation of Earth's Tertiary fold-mountain belts to horizontal thrust movements directed inland from the ocean, invoking the notion of continental collision to explain the formation of certain mountain ranges (e.g., Frank B. Taylor, 2015). His model of the "horizontal sliding of continental crust-sheets" was subsequently published in greater detail (Taylor, 1930). However, the hypothesis that the continents once formed a single landmass called Pangaea, before breaking apart and drifting to their present locations was first presented by Wegener (1912). He also introduced the term 'continental drift,' and a more complete version of the continental drift hypothesis was offered in Wegener (1929). The concept of 'seafloor spreading' was introduced by Holmes (1931) (Meyerhoff and Meyerhoff, 1987), who also indicated that mantle convection is a mechanism for continental drift (seafloor spreading) and offered the first model for such convection (see Fig. 2 in Holmes, 1931). Hess in 1960 (Meyerhoff and Meyerhoff, 1987; Hey, 2011), Dietz (1961), and Hess (1962) offered a new vision for the concept of seafloor spreading, which was adopted later by the plate tectonics model. Hess (1962) proposed a model in which mantle convection carried the seafloor and continents away from seafloor spreading centers (mid-ocean ridges), toward trenches. According to the model offered by Dietz (1961), the lithosphere moves on top of the plastic asthenosphere with convection currents.

The subduction process plays a pivotal role in the plate tectonics model. Ampferer and Hammer (1911) introduced the term "Verschluckungs-Zone" (literally, the swallowing-up zone: White et al. (1970)). André Amstutz (1951) was the first to introduce the word 'subduction' to replace the earlier term, in relation to the development of tectonic nappes in the Swiss Alps, and this was the term later recommended by White et al. (1970) for use in the plate tectonics model.

In 1967 and 1968 several papers (McKenzie and Parker, 1967; Morgan, 1968; Le Pichon, 1968; Isacks et al., 1968) offered a model which laid the groundwork of plate tectonics (Cox, 1973; McKenzie, 1977; Stewart, 1990). The model assumed that the earth's surface was composed of a set of rigid plates that were separated from each other by 
boundaries of different types, and that new seafloor was formed at ridge axes and destroyed in trenches (Stewart, 1990; Hey, 2011). Unfortunately, the model was offered as a package of highly generalized postulates, requirements, and assumptions, primarily of kinematic significance; yet it is still represented in this form with minor additions to this day:

(1) The Earth's surface consists of a number of rigid plates (e.g., Morgan, 1968) that move relative to one another. The rigidity of lithospheric plates is one of the fundamental tenets of plate tectonics (e.g., Solomon et al., 1975). These plates move at velocities of $1-10 \mathrm{~cm}$ per year (Richter, 1973).

(2) Main tectonic processes take place at plate boundaries, of which three types exist (e.g., Stewart, 1990; Meissner, 2002): (1) transform boundaries, (2) divergent boundaries (constructive; seafloor spreading centers), and (3) convergent boundaries (destructive; subduction).

(3) Transform faults (or boundaries), introduced by Wilson (1965), neither create nor destroy lithosphere; their relative motion is predominantly horizontal. These are the most important type of faults for plate tectonics (Hey, 2011).

(4) Mantle convection with large convection cells is the main cause of plate motion (e.g., Chapple and Tullis, 1977; Anderson, 1989). Convection currents are the driving force of Earth's tectonic system (e.g., Holmes, 1931, 1944).

(5) Under long sustained loads, the Earth's mantle behaves as a viscous fluid which will convect if heated from below or within, or cooled from above (Anderson, 1989).

(6) Thermal convection (as a whole) in some form is the only source of sufficient energy for tectonic processes (e.g., McKenzie, 1969). The energy for convection is provided by the decay of radioactive isotopes of uranium, thorium and potassium, as well as the cooling and crystallization of Earth (Anderson, 1989).

(7) Mantle convection could mean: whole-mantle convection with the dimensions of major lithospheric plates in the order of $10^{3}$ to $10^{4} \mathrm{~km}$ (e.g., Anderson, 1989); small-scale convection (vertical scale convection of 500 and $1000 \mathrm{~km})$ (e.g., Solomatov, 2004); stratified convection (e.g., Gutenberg et al., 1951; Jordan et al., 1989); within very weak upper mantle or asthenosphere (e.g., Elsasser, 1971); and plate-sized convection cells, or convection cell size as wide as the layer is thick (Bercovici et al., 2000).

(8) Mantle convection is caused by radiogenic heat produced by the radioactive decay of isotopes in the crust and mantle, and the primordial heat remaining from the formation of Earth (e.g., Turcotte and Schubert, 2002). This role of radi- ogenic heat in generating of mantle convection is greatly emphasized (e.g., Schubert et al., 1980; Davies, 1980, 2011; Turcotte and Schubert, 1982; Lyubetskaya and Korenaga, 2007; Lee, 2014).

(9) Mantle convection is a fundamental mechanism for the loss of primordial and radiogenic heat (e.g., Bercovici, 2011).

(10) Seafloor spreading (Dietz, 1961; Hess, 1962) is related to mid-ocean ridges and the creation of oceanic crust and upper mantle within them. Formation of new oceanic crust/lithosphere within mid-ocean ridges requires the destruction of lithosphere (its consumption) in subduction zones (for instance, within trenches and island arcs) (e.g., McKenzie, 1969).

(11) Subduction commonly involves convergence and underthrusting of adjacent lithospheric plates, but may also involve downfolding within a single plate (White et al., 1970). Initiation of subduction is a vital phase of the plate tectonic cycle (Gurnis et al., 2004), because it is the method of consumption and re-working of oceanic lithosphere formed in spreading centers. The lithosphere is consumed asymmetrically by island arcs (e.g., McKenzie, 1969). The subduction process requires dense rigid plates (e.g., Anderson, 2007). It is also viewed as a method of cooling Earth's interiors (e.g., Stern, 2007) and delivering water to deep levels within the mantle.

(12) The subducting slab is colder than the mantle (Elsasser, 1969; McKenzie, 1969; Chapple and Tullis, 1977; Bina et al., 2001; Wessel and Müller, 2009; Kirdyashkin and Kirdyashkin, 2014) and must be denser than mantle rocks. The cooling subducting lithosphere is heavier than the underlying mantle and therefore drags the attached plate (Elsasser, 1967; Cruciani et al., 2005). The oceanic lithosphere is isostatically sinking away from the mid-ocean ridge as it cools and densifies (Wilson, 1993). Slab buoyancy provides the primary driving force for subduction (e.g., Forsyth and Uyeda, 1975; Chapple and Tullis 1977). Plate tectonics is driven by negative buoyancy of the outer shell (Richardson, 1992; Anderson, 2001). This negative buoyancy of the slab is proportional to the age of the oceanic lithosphere (Cruciani et al., 2005). Buoyant slab material entering the subduction system steepens the slab angle and reduces the velocity of the trench (Royden and Husson, 2009). The negative buoyancy of a subducting oceanic slab provides a peak subduction rate of $5 \mathrm{~cm}$ per year (Mahatsente and Ranalli, 2004). 
(13) The sinking slab must be brittle enough to produce earthquakes by fracturing, and sufficiently undeformable to maintain its shape at a depth of $600 \mathrm{~km}$ (Sykes, 1966). The concept of rigid plates with deformations primarily concentrated near plate boundaries provides a comprehensive understanding of the global distribution of earthquakes (Isacks et al., 1968). The motion of a slab is well known from the location of deep earthquakes (Sykes, 1966). Earthquakes are restricted to those regions of the mantle which are colder than a certain temperature (e.g., McKenzie, 1969). There is an apparent relationship between the depths of the deepest earthquakes and the temperature distribution within the sinking lithosphere (e.g., McKenzie, 1969). Plate tectonics has related seafloor spreading to the focal mechanisms of earthquakes (e.g., McKenzie, 1969). The relative motion between plates may be determined from these focal mechanisms (McKenzie and Parker 1967; Isacks et al., 1968).

(14) Plate boundary and plate body forces are responsible for the initiation of plate movements. These primary forces are: basal drag, ridge push, slab pull, trench suction, and collisional resistance (e.g., Richardson, 1992).

(15) Plate tectonics is a far-from-equilibrium selforganized system (Anderson, 2001, 2002, 2007; Stern, 2007).

(16) Plate tectonics is a late-stage method for cooling off the interior (e.g., Anderson, 2007).

Peculiarities of plate tectonic processes are described in: McKenzie and Parker (1967), Le Pichon (1968), Morgan (1968), McKenzie (1969), Cox (1973), McKenzie (1977), Cox and Hart (1986), Turcotte and Schubert (1982, 2002), Anderson (1989, 2001, 2002, 2007), Kearey et al. (2009), Wessel and Müller (2009), Kirdyashkin and Kirdyashkin (2014).

Hey (2011) notes that a key step in building the plate tectonics model was Wilson's (1965) conclusion that the deformation of Earth's crust is concentrated in narrow mobile belts that are interconnected in a global network. Hey (2011) calls this introduction of transform faults and other ideas presented in Wilson (1965) as the first qualitative model of plate tectonics. McKenzie (1969, p. 2) also believed that "Wilson stated the basic assumptions of plate theory, but made no further use of them."

Among other mobilist models related to plate tectonics here should be mentioned: the Wilson cycle, formation and breakup of supercontinents, and the Benioff zone (Benioff, 1949, 1954).

Wilson (1966) offered a tectonic model now known as the "Wilson cycle" (e.g., Whitmeyer et al.,
2007; Burke, 2011). According to this model, overall tectonic evolution follows alternating cycles of oceanic opening and closing (e.g., Atlantic Ocean). Wilson (1965) identified six specific stages within each cycle (e.g., Jacobs et al., 1973): 1) embryonic (uplifts); 2) young (spreading); 3) mature (spreading); 4) declining (shrinking); 5) terminal (shrinking and uplifts); 6) relic scar or geosuture (shrinking and uplift). Silver (2007, p. 30) characterized this model as follows: "This alternating ocean opening and closing, continental breakup and continental collision - now termed the Wilson Cycle - is arguably the single most important principle in continental evolution, providing an elegant explanation for the semi-periodic creation of mountain chains throughout Earth's history." Subsequent researchers proposed a nine-stage model of the Wilson cycle (e.g., Whitmeyer et al., 2007) containing the following stages: A) stable craton; B) hot spot/rifting; C) early divergent margin; D) full divergent margin; E) volcanic arc mountain building; F) island arc/continent collision; G) cordilleran mountain building; H) continent-continent mountain building; I) stable continental craton. This model was also used to propose a series of supercontinents assembled and broken up during Earth's evolution (e.g., Santosh et al., 2009; Nance and Morphy, 2013; Pastor-Galán et al., 2018).

Corresponding to the Wilson Cycle (1965), the most ancient oceanic crust is usually restricted to the Middle Jurassic (175-180 Ma); with some investigators indicating a maximum age limit dating to the end of the Jurassic ( 200 Ma) (e.g., Cogné et al., 2006; Хаин, 2001; Хаин, Короновский, 2007). This is because the Wilson Cycle requires periodic reworking of the oceanic crust in subduction processes, consuming the older oceanic lithosphere. However, a comparatively recent study in the Eastern Mediterranean on the basis of combined magnetic-paleomagnetic-gravity-seismic and tectonicstructural-petrological-radiometric analyses has revealed the Kiama paleomagnetic hyperzone of inverse polarity (Figure 1) (Eppelbaum et al., 2014; Eppelbaum, 2015; Eppelbaum and Katz, 2015a,b). This zone covers a period between 293-242 Ma (47 million years) within the Permian epoch and its discovery contradicts the Wilson Cycle, which assumes that age of the most ancient oceanic crust should not exist beyond 180-200 Ma. It is necessary to note that the theoretical possibility of the presence of more ancient oceanic crust (230-270 Ma) in the Mediterranean Sea was displayed earlier in Müller et al. (2008) and Stern and Scholl (2010). However, practically identifying this large block of ancient oceanic crust, the Kiama paleomagnetic hyperzone necessitates further correction of the Wilson Cycle. 


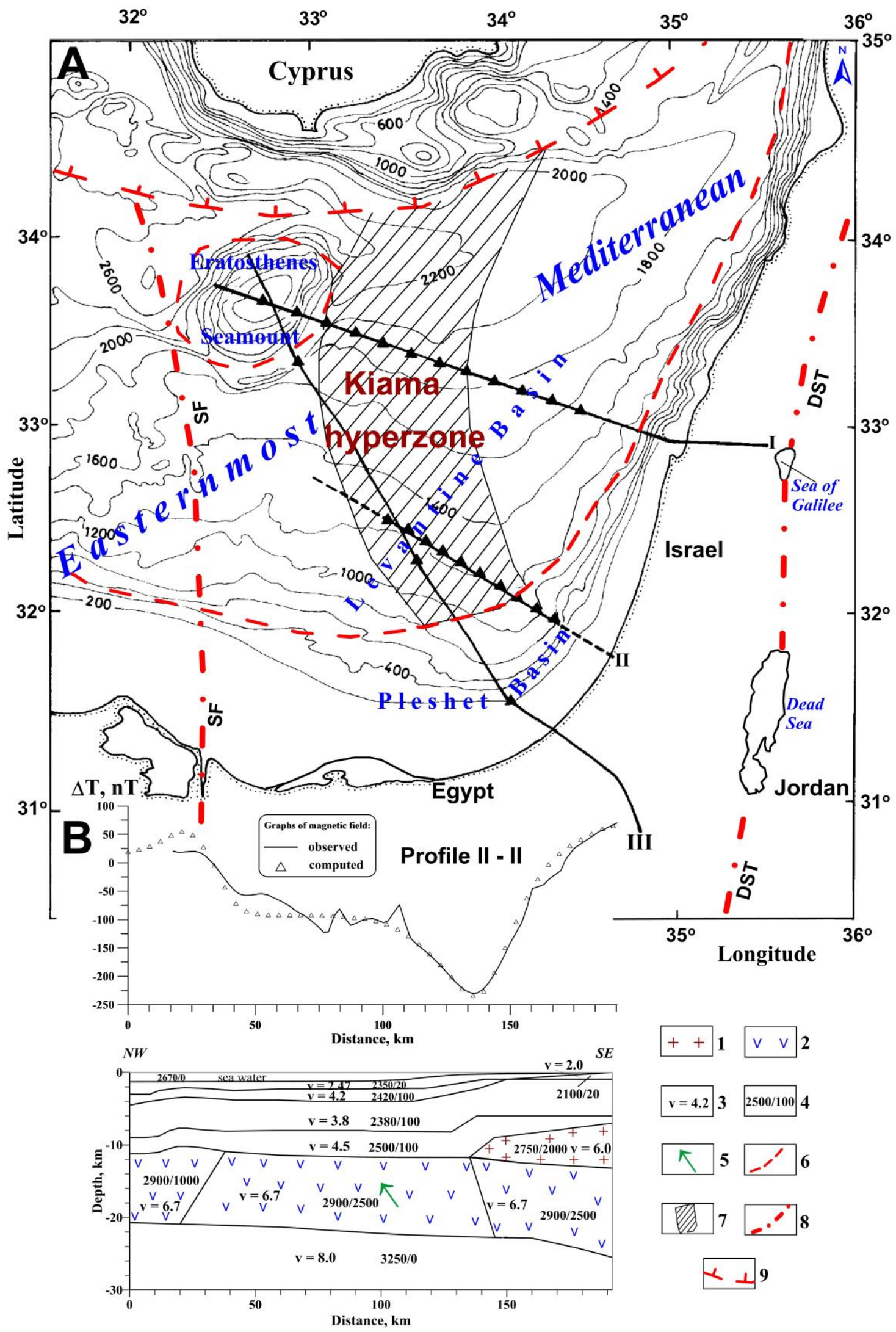

Fig. 1. A: Location of seismic-gravity-magnetic profiles placed on the bathymetric map, B: Results of 3D magnetic field modeling along profile II - II (similar results were received for profiles I - I and III - III). 1 - granitic layer, 2 - basaltic layer, 3 - seismic velocity, $\mathrm{km} / \mathrm{s}, 4$ - physical properties (numerator, density, $\mathrm{kg} / \mathrm{m}^{3}$, denominator, magnetization, $\mathrm{mA} / \mathrm{m}$ ), 5 - direction of the magnetization vector other than the geomagnetic field inclination of the region, 6 - boundary discovered between the continental and oceanic crust within the Sinai plate, 7 - delineated contour of the Kiama paleomagnetic zone, 8 - interplate deep faults of the Eastern Mediterranean: SF, Sinai Fault and DST, Dead Sea Transform, 9 - deep fault separating the Alpine Belt and oceanic depression of the Easternmost Mediterranean (after Eppelbaum and Katz (2015a), with modifications). 
A number of supercontinents have been proposed to exist on Earth at different time periods (e.g., Zhao et al., 2002, 2004 and references therein): Vaalbara (between $\sim 3.6$ and $\sim 2.8 \mathrm{Ga}$ ); $\mathrm{Ur}$ (at $\sim 3 \mathrm{Ga}$ ); Kenorland (between $\sim 2.7$ and $\sim 2.1 \mathrm{Ga}$ ); Columbia (between $\sim 1.8$ and $\sim 1.5 \mathrm{Ga}$ ); Rodinia (between $\sim 1.25 \mathrm{Ga}$ and $\sim 750 \mathrm{Ma}$ ) and Pannotia (at $\sim 600 \mathrm{Ma}$ ). Fragments of the breakup of the supercontinent Pannotia are believed to have ultimately collided and formed the supercontinent Pangaea, which in turn broke up during the opening of the Atlantic Ocean and closing of the Greater Tethys between 203-125 Ma (e.g., Keppie, 2015) to form Laurasia and Gondwanaland.

Benioff (1949) introduced a method for determining planes of seismicity along a particular fault. Such planes applied to plate tectonics were named Benioff zones (or Wadati-Benioff zones) (e.g., Condie, 1987; Hasegawa and Takagi, 1987; Zhao et al., 1997). Condie (1987) especially indicates that in terms of plate tectonics, the Benioff zone is the site of plate consumption and often referred to as a subduction zone. This assumption allows hypocenters and the distributions of deep earthquakes to be used in tracing subduction zones.

\section{Main forces operating in plate tectonics processes}

Classical mechanics, also known as Newtonian mechanics, is composed of three main segments: kinematics (describing the motion of material points, objects and systems of objects without consideration to the causes of motion); dynamics (describing the motion of objects under the influence of forces); and statics (describing bodies at rest and forces in equilibrium). Since moving plates have limited velocities, their movement must satisfy the corresponding laws of classical mechanics (Pilchin, 2016b). However, from this point of view, most of the earliest publications on plate tectonics (e.g., McKenzie and Parker, 1967; Morgan, 1968 and many others) were only concerned with the kinematics of plate motion, rather than the causes of their movement (e.g., Stewart, 1990). Unfortunately, the authors of most subsequent articles were also generally more concerned with the kinematic part of plate motion, rather than its dynamics. This brings us to today, where the dynamics of plate motion are still greatly underdeveloped. Pratt (2000, p. 342) states that "There is no consensus on the thickness of the 'plates' and no certainty as to the forces responsible for their supposed movement." This can be clearly seen from the forces postulated to operate in plate tectonics, as they are described in the most general form with very little or no detail, and seldom actually used in discussing plate movements.
Alvarez (1990) also notes that even though the plate tectonics model has been nearly universally accepted, researchers still do not understand the driving mechanisms in anything other than the most general terms. In plate tectonics, where dynamics is the fundamental element, as the motion of a plate results from forces perpetually applied to it, it is absolutely crucial for the precise forces to be explained in detail. In the early years of developing the plate tectonics model, McKenzie $(1969$, p. 3) wrote that: "The major remaining problem in plate theory is the driving mechanism."

It has been yet another quarter century since Wilson (1993) noted how earth scientists have debated the nature of the forces which drive the lithospheric plates for more than a quarter of a century. "Plate tectonics offers no explanation for the forces that drive plates" (Frankel, 2012; Introduction, p. XXI). Lyttleton and Bondi (1992; p. 195) state that "A further difficulty with the plate-tectonic hypothesis is the absence of even a notional causative force for the plate movements" and "the absence of an identifiable driving force and a quantitative analysis of the source of the alleged motions remains, in our view, the biggest gap in the plate tectonics theory." The forces that were once postulated with no satisfactory explanation therefore remain unchanged from the time of their conception until now (e.g., Kirdyashkin and Kirdyashkin, 2014), because most publications still define these forces as they were in the very beginning, lacking any viable detail. Frankel (2012; Introduction, p. XXI) gives his full support to this situation, stating: "Ironically, it is remarkable that plate tectonics was accepted almost immediately even though it is a kinematic not a dynamic theory. Once accepted, the lack of mechanism was no longer a difficulty but an advantage, freeing the discussion of the relentless and unnecessary burden it had carried for so long." Bercovici (2003, p. 108) also points out that there has been little to no change in vision of the plate tectonics model: "Many students of geology are taught how mantle convection drives plate tectonics in much the same way that Arthur Holmes envisioned it 70 years ago, i.e. convective 'wheels' driving the tectonic "conveyor belt." However, as they say, the devil is always in the details.

There are a number of traditional driving forces that were postulated for plate tectonics, which include: slab pull, ridge push, basal drag, trench suction, and collisional resistance (e.g., Forsyth and Uyeda, 1975; Richardson, 1992; Wilson, 1993). These forces are generally treated as either plate boundary or plate body forces. For example, ridge push is considered both: a body force caused by cooling and thickening of the oceanic lithosphere with age (e.g., McKenzie, 1969; Richardson, 1992); 
and a boundary force caused by the 'gravity wedging' effect (Bott, 1993).

Slab pull forces are believed to originate from the negative buoyancy of the cold subducting lithosphere (e.g., Chapple and Tullis, 1977), and is considered a boundary force (e.g., Wilson, 1993). In slab pull, it is assumed that the slab is mechanically attached to the subducting plate, and its weight will pull on the subducting plate, drawing it toward the subduction zone (e.g., Conrad and LithgowBertelloni, 2002). Slab pull is usually considered one of the dominant acting forces, and may account for roughly half of the total driving force exerted in plate movement (Anderson, 2007).

Basal drag (or basal shear traction) is associated with the interface between the upper mantle and the lithosphere and is caused by mantle convection (Wilson, 1993).

Trench suction forces are usually observed in the overriding plate at subduction zones as a net trenchward pull (Forsyth and Uyeda, 1975; Chase, 1978). In the slab suction mechanism, it is usually assumed that slabs are detached from their surface plates and sink within the upper mantle (e.g., Conrad and Lithgow-Bertelloni, 2002).

Collisional resistance force directly opposes the slab pull force (e.g., Richardson, 1992). This occurs because the mantle resists subduction to some extent due to friction and when continental plates collide (e.g., Cloetingh and Wortel, 1986). Such forces are considered to be only locally significant (e.g., Cloetingh and Wortel, 1986).

There is no consensus among researchers about the importance of one main force compared to the others (e.g., Wilson, 1993), and in the case of the basal drag force even any indication of it operating at all is uncertain (e.g., Richardson, 1983; Anderson, 2007).

Some researchers consider basal drag as a passive force, either driving or resisting plate motion, but not dominating it (e.g., Chapple and Tullis, 1977; Richardson, 1992), while drag due to classical Rayleigh-Bénard convection in the upper mantle is not an adequate driving force (Richter, 1973; Solomon et al., 1975). However, Chapple and Tullis (1977) state that motion of lithospheric plates is a manifestation of convection, while other researchers believe that mantle forces related to large convection cells dominate the driving forces (e.g., Jacoby, 1980). Ziegler (1993) also believes that the basal drag (shear-traction) force exerted by the convecting asthenosphere on the base of the lithosphere plays an important and sometimes even dominant role as a plate-moving mechanism.

Ziegler (1992) states that in the Western Hemisphere frictional forces exerted on the base of the lithosphere by the slowly convecting sub-litho- spheric upper mantle play a key role as the driving mechanism of plate movements, and such forces as slab-pull and ridge-push can be considered secondary. At the same time, in a formula for determining plate velocity Carlson (1981) marks basal drag force as negative (opposing plate movement). Forsyth and Uyeda (1975) also indicate that drag on the bottom of plates resists motion, and would be stronger under continents than under oceans. Richardson (1983) questions whether the drag force is negative or positive as well. Bercovici (2003, p. 108) openly accuses some researchers (e.g., Jurdy and Stefanick, 1991; Anderson, 2001) of stepping back from the main postulates of the plate tectonics model, stating that: "... there are several fundamental aspects of it that are misleading at best; in particular, it portrays the plates and convection as separate entities, with convection currents prying open mid-ocean ridges and dragging down subducting slabs. The other limit of plate models disregard convection, referring instead to preexisting plates moved by forces such as slab pull and ridge push ... that are somehow unrelated to the convective energy source that fuels these forces ...". If mantle convection with large convection cells is the main cause of plate motion (e.g., Chapple and Tullis, 1977; Anderson, 1989), and convection currents are the driving force behind the Earth's tectonic system (e.g., Holmes, 1931, 1944), how could it be that the drag force generated by mantle convection would not be the most significant force?

Certain researchers presume that plate motions are mostly dictated by ridge push and subduction pull forces (e.g., Dewey, 1988; Anderson et al., 1992; Lithgow-Bertelloni and Richards, 1995; Anderson, 2001; Buiter et al., 2001; Conrad and Lithgow-Bertelloni, 2002). Cruciani et al. (2005, p. 298) states that: "During the last years has become quite popular the idea that the slab pull is primarily driving plate tectonics." Bott (1993, p. 949) comes to the conclusion that "It has been tacitly assumed by the author that the plates are essentially driven by edge forces such as ridge push and subduction pull, rather than by underside frictional drag exerted by mantle convection."

Chapple and Tullis (1977) consider the ridge push force as very minor. They believe in the importance of the different forces acting on plates, due to the fact that each of them has an unknown sign and magnitude. Wilson (1993) states that the relative importance of the different forces involved may vary both in the space and time, and they may either reinforce or counterbalance each other depending upon the tectonic setting.

Forsyth and Uyeda (1975) suggest that the forces exerted on a downgoing slab dictate the velocity of attached oceanic plates, being an order of magni- 
tude stronger than any other force, and causing any oceanic plates attached to substantial amounts of downgoing slabs to move with 'terminal velocity.' They assert that at such velocity, the gravitational body force pulling the slab downward would be nearly balanced with the resistance acting upon the slab, regardless of other features of the trailing plate.

However, some researchers also emphasize the importance of resisting forces. Buiter et al. (2001) showed that plates are largely driven by slab pull and ridge push forces, which are counteracted by resistive forces (e.g., plate contact resistance and viscous resistance). Forces resisting drag beneath continents and net pull toward trenches on upper plates are small but significant (Chapple and Tullis, 1977). Tectonic resistive forces are considered equal and opposite in sign to the force exerted on the subducting plate, and therefore do not contribute greatly to the net driving force of plate motion (Meijer and Wortel, 1992). Wilson (1993) asserts that plate tectonic resistive forces are exerted on the overriding plate in a subduction zone at the interface with the descending slab.

Other researchers believe that plate tectonics is a far-from-equilibrium self-organized system (Anderson, 2001, 2002, 2007; Stern, 2007). Bird (1998, p. 115) states that "... it became natural to regard plates of lithosphere as driving themselves and, incidentally, stirring the rest of the mantle." Hamilton (2002) further believes that upper mantle convection is a product, not a cause, of plate motion.

At the same time, many researchers have consistently pointed out the persistent problems in understanding the processes driving lithospheric plates. In the 1970s, Forsyth and Uyeda (1975, p. 164) noted how "... rather little is known about the driving mechanisms of plate tectonics, although various types of forces have been suggested." In the 1980s, Alvarez (1982) wrote that "the driving mechanism of plate tectonics remains elusive." In the 1990s, Wilson (1993) stated that the processes which drive the lithospheric plates were still not fully understood, and Kerr (1995) indicated that the next central unsolved mystery was: What drives plates in the first place? Bokelmann (2002, p. 1027) stated that "Although the concept of plates moving on Earth's surface is universally accepted, it is less clear which forces cause that motion," while Schellart (2004) pointed to the considerable debate about the driving forces of tectonic plates and their relative contribution. More recently, Van Andel (2015) specified that: “... the lithospheric plates move across Earth's surface, driven by forces as yet not fully understood ..."

Some scientists have also suggested that plate tectonics may be triggered by the effect of tidal vari- ations across many hundreds of millions of years (influence of the Moon and Sun's gravity) (Riguzzi et al., 2010; Eppelbaum and Isakov, 2015). However, there is currently no theoretical or practical methodology for testing this hypothesis.

Certain researchers (e.g., Skobelin et al. (1990); Хаин, (2001)) indicate that the plate tectonics model cannot account for intraplate (platform) magmatism (e.g., traps, platobasalts, kimberlites) and metallogeny. From this point of view, the discovery of a giant quasi-ring counterclockwise-rotating structure in the Earth's mantle centered below the Cyprus Island holds significant importance (Eppelbaum et al., 2020; Eppelbaum and Katz, 2020). This deep structure helps explain the linear nature of continental magmatism, which had not been previously given sufficient tectonic-geophysical justification.

As a rule, any net force different from zero must create acceleration in the direction of the net force. At the same time, terminal velocity is achieved only when the forces of friction are overcome by the other forces applied to the plate. Consequently, a subducting plate must either move with acceleration or not move at all.

All of the abovementioned illustrates how there is no clear definition of the forces operating in plate tectonics and plate movement. In none of the cases the role of different forces is made clear, and in many it is not yet understood. In over fifty years since introducing the plate tectonics model, the question "What are the forces that drive plate movement?" still remains unanswered, and the answer is long overdue.

Did plate tectonics operate in the Hadean and Early Archean?

Determining when plate tectonics began on Earth is among the most important and enigmatic problems in modern day geology. However, here it is most important to learn whether plate tectonics operated during the early Earth evolution (mostly the Hadean - Early Archean).

Based on an analysis of the detrital zircons from Jack Hills (Western Australia), Harrison et al. (2005) concluded that a continental crust with volume similar in magnitude to the present day crust had formed by 4.4 to $4.5 \mathrm{Ga}$, and was rapidly recycled into the mantle. Many recent investigations established the geochemistry of Hadean zircons from the Jack Hills (Yilgarn Craton, Western Australia) (ranging from ca. 4.4 to $3.0 \mathrm{Ga}$ ), showing that their Hf isotope compositions suggest dominant sourcing from the ancient felsic crust (Bell, 2013). Nebel et al. (2014) also indicate that previous researches from Jack Hills contain detrital zircon grains with ages as old as $4.37 \mathrm{Ga}$ which are 
rare remnants of the Hadean (4.5-4.0 Ga) terrestrial crust, and only a small proportion of detrital zircons shows the Hadean age spectra. On top of this, younger overgrowth rims on all 'Hadean' grains indicate multiple recycling events. Their elemental and isotope budget and mineral inclusions were utilized in postulating the presence of an evolved water-rich Hadean crust. The use of these zircons for proposing that plate tectonics operated in the Hadean is in many cases self-evident (e.g., Maruyama et al., 2016). Really, if we accept that these zircons are remnants from a continental crust that somehow disappeared sometime in the Hadean, it is easy to surmise that the Hadean crust was simply recycled into the mantle over the course of plate tectonic processes. These zircons found in the Jack Hills area (Yilgarn Craton of Western Australia) are held as evidence of the presence of a continental crust and oceans at the time of their formation, with the oldest being nearly $4.4 \mathrm{Ga}$ based on its $\delta^{18} \mathrm{O}$ values (Peck et al., 2001; Wilde et al., 2001).

Analysis presented in (Wilde et al., 2001) demonstrates that this oldest zircon is zoned with respect to rare earth elements and oxygen isotope ratios $\left(\delta^{18} \mathrm{O}\right.$ values vary from $7.4 \%$ to $5.0 \%$ ), and that some data point to its growth from a granitic melt. However, it is not the isotope $\delta^{18} \mathrm{O}$, but some very specific rocks which can be formed only within oceanic environments (e.g., carbonates, evaporites, the presence of oceanic crust fragments (ophiolites, peridotite layer)) that characterize the presence of a water ocean, yet none of these rocks are known for this period. This then places doubts on the existence of a water ocean in the Hadean (e.g., Pilchin and Eppelbaum, 2009; Eppelbaum et al., 2014). Different scientists have come to conclusions that Earth's oceans were formed as early as: by $\sim 4.5 \mathrm{Ga}$ (Condie, 1989), in the Hadean (Morse and Mackenzie, 1998), at $4.4 \mathrm{Ga}$ (Peck et al., 2001; Wilde et al., 2001; Valley et al., 2002; Liu, 2004), 4.3 Ga (Lowe, 1994; Mojzsis et al., 2003), by 4.2 Ga (Sleep et al., 2001; Mojzsis et al., 2003), by 3.85 Ga (Nutman et al., 1997), by 3.8 Ga (Lambert, 1982; Nisbet and Sleep, 2001), by 3.6 Ga (Grotzinger and Kasting, 1993), $3.5 \mathrm{Ga}$ (Knauth and Lowe, 2003; Nunn, 1998).

Contrastingly, Pilchin and Eppelbaum (2012) have shown that the oldest zircon of up to $4.4 \mathrm{Ga}$ found in the Jack Hills area does not prove that oceans were necessarily present at the time of its formation, as there could have been numerous other causes for the elevation of $\delta^{18} \mathrm{O}$ values in this zircon. A number of facts will be found to contradict the presumption that $\delta^{18} \mathrm{O}$ values within the zoned zircon of $4.4 \mathrm{Ga}$ (from the Jack Hills area) indicate the existence of oceans prior to about $4.4 \mathrm{Ga}$. Since the zircon was grown from a granitic melt, its $\delta^{18} \mathrm{O}$ content should not be compared with the standard mantle $\delta^{18} \mathrm{O}$ content, especially as granitic melts are not usually formed in the mantle. Data of Peck et al. (2001) and Wilde et al. (2001) show that zircons from the Jack Hills area are characterized by $\delta^{18} \mathrm{O}$ values of about: $7.4 \%$ at $4.353 \mathrm{Ga}, 5.7 \%$ at 4.15 $\mathrm{Ga}, 7.2 \%$ at $4.13 \mathrm{Ga}, 6.8 \%$ at $4.01 \mathrm{Ga}$, and $6.3 \%$ at 3.6-3.3 Ga, which would suggest that oceans existed at some periods, but not in other periods of the Hadean-Archean. The strong relationship between $\delta^{18} \mathrm{O}$ values and the formation temperature of quartz $\left(\mathrm{SiO}_{2}\right)$ should indicate that there were drastically fluctuating temperatures during the HadeanArchean.

According to experimental data derived from zircons discovered in the Jack Hills area and the relationship between the $\delta^{18} \mathrm{O}$ values and the temperature of quartz formation (Clayton et al., 1972; Spooner et al., 1974), the temperatures during the formation of those zircons were greater than 583$623 \mathrm{~K}$. Based on the micro-inclusions of $\mathrm{SiO}_{2}$ in zircons from the Jack Hills area, Wilde et al. (2001), Valley et al. (2006) and Harrison et al. (2006) came to the conclusion that the zircons formed from silica-saturated granitic or granitoid magma. However, silica-saturated magmas are known for the high $\delta^{18} \mathrm{O}$ content in quartz (Mariano et al., 1990; Knight et al., 2000), which may have been a possible cause for the elevated $\delta^{18} \mathrm{O}$ values of some grains of these zircons. Moreover, $\delta^{18} \mathrm{O}$ values are higher for quartz formed at relatively higher temperatures (Mariano et al., 1990; Gallagher et al., 1992; Knight et al., 2000). Temperature estimations indicate that Jack Hills zircons ranging from 4.0 to 4.35 Ga yielded crystallization temperature peaks at $943 \mathrm{~K}$ and $983 \mathrm{~K}$ (Harrison and Watson, 2005), which would be favorable for the elevated $\delta^{18} \mathrm{O}$ values in quartz and some zircons (Pilchin and Eppelbaum, 2009). Research also shows that $\delta^{18} \mathrm{O}$ values are high for carbonates (Ducea and Saleeby, 2003; Sharp et al., 2003), $\mathrm{CO}_{2}$ (Sharp et al., 2003), and sulfates (Bindeman et al., 2007). This means that the zircons of Jack Hills could have become enriched with $\delta^{18} \mathrm{O}$ through contact with carbonate or sulfate rocks, or with $\mathrm{CO}_{2}$ itself from the early Earth atmosphere (Pilchin and Eppelbaum, 2012). Elevated $\delta^{18} \mathrm{O}$ values for barite from the Pilbara block of Western Australia (Richards et al., 2001) and Barberton Mountland of South Africa (Gutzmer et al., 2006) also point to the possible involvement of sulfates and $\mathrm{SO}_{2}$ in the elevated $\delta^{18} \mathrm{O}$ values of the zircons from the Jack Hills area of the Yilgarn Craton (Pilchin and Eppelbaum, 2009). Conversely, data of Fehlhaber and Bird (1991) have 
shown that some minerals in gabbros that have been in contact with supercritical water (which was widely present in the early Earth atmosphere (Pilchin and Eppelbaum, 2012; Eppelbaum et al., 2014)) actually have lowered values of $\delta^{18} \mathrm{O}$.

Pilchin and Eppelbaum (2012) note that taking all of these details into account, it is more likely that the zircons from the Jack Hills area represent the first or one of the first attempts of Earth crust formation. The only thing certain about those zircons is the fact that after formation they were never again heated above $\sim 1173 \mathrm{~K}$, or their age records would have been completely erased. It is also clear that the presence of an ocean is not necessary to form a zoned zircon with $\delta^{18} \mathrm{O}$ values in some grains a little bit higher than those of the average mantle (Pilchin and Eppelbaum, 2009, 2012). This also means that such zircons existing in a local isolated place (or even several places) likewise would not indicate the existence of plate tectonics in the Hadean. This is in agreement with results of other researches. For instance, Shirey et al. (2008) come to the conclusion that subduction was initiated by $3.9 \mathrm{Ga}$ or at least by 3.5 Ga. They also dismiss the idea that Hadean zircons aged between 4.4 and $4.0 \mathrm{Ga}$ were formed in continents, stating instead that they were most likely derived from a continent-absent, mafic to ultramafic protocrust that was remelted multiple times between 4.4 and $4.0 \mathrm{Ga}$.

Based on an investigation of the over 4-billionyear history of the Jack Hills zircons, Bell (2013) interprets the $\mathrm{Hf}$ isotope record as evidence of subduction-related recycling, mainly from the ancient Hadean crust at ca. 3.8-3.7 Ga. Nebel et al. (2014) also state that the Hadean detrital zircon grains from the Jack Hills area of the Narryer Terrane (Western Australia's Yilgarn Craton) were formed not within the granitic continental crust, but within the initially homogeneous thin mafic layer. They believe that late heavy bombardment (3.85-3.90 $\mathrm{Ga}$ ) is related to the onset of Archean-style tectonics, likely associated with subduction activity and lasting until $\sim 3 \mathrm{Ga}$, when modern style plate tectonics emerged. On the other hand, it was shown earlier (Pilchin and Eppelbaum, 2012; Eppelbaum et al., 2014) that formation of oceans on Earth only began at the end of the Early Archean, at 3.42$3.26 \mathrm{Ga}$ (most likely at $\sim 3.26 \mathrm{Ga}$ ).

Among other researches pointing to the possibility of plate tectonics operating in the HadeanEoarchean, the following should be mentioned here. Based on analysis of the Hadean to Eoarchean, Turner et al. (2014) point to the possibility of subduction of Earth's crust and modern-day plate tectonics in the Hadean. De Wit (1998) presumes that the formation of oceanic lithosphere started from $\sim 4.5 \mathrm{Ga}$, the hydrosphere was accumulated by about $4.0 \mathrm{Ga}$, and modern plate tectonics probably started between 4.2 and 4.0 Ga. Ernst (2009) argues that by $\sim 4.3 \mathrm{Ga}$ shallow seas were present, so surface temperatures had fallen well below the (1) $1573 \mathrm{~K}$, (2) $\sim 1393 \mathrm{~K}$, and (3) $\sim 1223 \mathrm{~K}$ (temperatures which are much greater than those of the liquefaction of atmospheric water from the early Earth (Pilchin and Eppelbaum, 2012; Eppelbaum et al., 2014)) for lowpressure solidi of (1) peridotite, (2) basalt, and (3) granite, and he proposes there was growth of the oceanic and continental plates during 4.4-2.7 Ga.

Based on analysis of Hadean to Eoarchean rocks from Nuvvuagittuq Greenstone Belt (Canada), O'Neil and Carlson (2014) suggest that a process similar to subduction, if not subduction itself, was active as early as in the Hadean or Eoarchean. Sleep (2010) states that the Earth began hot after the moon-forming impact, and cooled to the point where liquid water was present within about 10 million years. He also believes that a warm $500 \mathrm{~K}, 100$ bar $\mathrm{CO}_{2}$ greenhouse persisted until subducted oceanic crust sequestered $\mathrm{CO}_{2}$ into the mantle, mentioning as an example carbonate subduction by $4.26 \mathrm{Ga}$ in India, and indicating that mantle-derived rocks, especially kimberlites and similar $\mathrm{CO}_{2}$-rich magmas, preserve evidence of the subducted upper oceanic crust. Foley et al. (2014) argue that subduction was possible in the Hadean's Earth (referring to it as proto-subduction or proto-plate tectonics), and that this proto-subduction tectonics differed from modern plate tectonics. They state that at high mantle temperatures of $\sim 2000 \mathrm{~K}$, the mode of subduction switches to a "sluggish subduction" style. They also indicate that a number of models of post-magmaocean mantle convection demonstrates that protoplate tectonics likely initiated within $\sim 100$ My of the magma ocean's solidification. Arndt and Nisbet (2012) state that after the Moon-forming event occurred at $\sim 4.5 \mathrm{Ga}$, the ocean/atmosphere system and uppermost few kilometers of the crust cooled within a few million years and, if early subduction were efficient, this could have taken as little as 10 million years, leaving a cold lifeless Earth, its oceans white with ice. They also suggest that from $\sim 4.4$ to $4.0 \mathrm{Ga}$, wide areas of the planet may have been covered in lava flows beneath a deep ice-covered ocean.

Many researchers believe that plate tectonics started in the Archean (Bercovici, 2003; Shervais, 2006) or even in the beginning of the Early Archean (probably from $3.8 \mathrm{Ga}$; Shervais, 2006). At the same time, the initiation of recognizable platetectonic processes occurred by 3.0 Ga (Shervais, 2006). Tatsumi et al. (2015) found mounting evidence that both ocean formation and plate tectonics operation took place in the Early Archean between 
3.6-3.9 Ga. Nutman et al. (2002) report horizontal movements in the Isua supracrustal belt between 3.65-3.60 Ga, and propose that some form of plate tectonics was operational back then. Kröner and Layer (1992) state that rigid continental plates must have existed since at least $3.5 \mathrm{Ga}$. Based on paleomagnetic, geochemical and tectonostratigraphic data, Cawood et al. (2006) establish that plate tectonics have been active since at least $3.1 \mathrm{Ga}$. Condie and Kröner (2008) also state that modern plate tectonics were operational at least in some regions on Earth since $3.0 \mathrm{Ga}$, or even earlier, and that they became widespread since $2.7 \mathrm{Ga}$. Rapp et al. (2008) indicate the appearance of monzodiorites and trachyandesites of the sanukitoid suite in $~ 3.0-2.8$ $\mathrm{Ga}$, marking it the beginning of "modern-style" plate tectonic subduction. Calvert et al. (1995) discuss the following items: (1) start of plate tectonics at $\sim 1.89 \mathrm{Ga}$ in the Svecofennian orogen (Fennoscandian Shield); (2) inferred plate convergence, subduction and accretion in the Trans-Hudson orogen (Precambrian Canadian Shield and North American Craton) at 1.91-1.79 Ga; and (3) combining seismic data with geochronology and structural mapping to identify the collision zone in the Superior Province of Canada (involving the Abitibi Subprovince and the Opatica belt), which represents a relict $2.69 \mathrm{Ga}$ suture associated with subduction, thereby arguing this is a period of active plate tectonics.

Sizova et al. (2010) used numerical modeling to identify a first-order transition from a "nosubduction" tectonic regime (with upper-mantle temperatures $>250 \mathrm{~K}$ higher than present), through a "pre-subduction" tectonic regime (upper-mantle temperatures $175-250 \mathrm{~K}$ higher than present), to the modern form of subduction (when upper mantle temperatures dropped below 175-160 K higher than present). These results suggest that the transition to the modern plate tectonic regime may have occurred during the Mesoarchean-Neoarchean period ( 3.2$2.5 \mathrm{Ga}$ ). Grove and Parman (2004) distinguish that the decline in the abundance of komatiites from the Archean to the Phanerozoic is evidence of secular cooling of the mantle (up to $773 \mathrm{~K}$ between $3.5 \mathrm{Ga}$ and today). In another model they show hydrous melting at shallow mantle depths in a subduction environment within the Archean mantle to produce komatiites at only slightly hotter temperatures than at present $(\sim 373 \mathrm{~K})$, indicating that subduction operated in the Archean.

Some researchers point out that the hotter mantle ( 200 K hotter, e.g., Hamilton, 1998, 2007b; $\sim 175-250 \mathrm{~K}$ hotter, e.g., Sizova et al., 2010) during early periods of Earth's evolution (such as the Archean) would produce a thick and buoyant crust that could pose a problem for subductability of the oceanic lithosphere (e.g., Hamilton, 1998, 2007b; Korenaga, 2008). Hamilton (2007b) shows that mantle temperatures are likely to have been hotter than at present by about $300 \mathrm{~K}$ at $3.5 \mathrm{Ga}, 200 \mathrm{~K}$ at $2.5 \mathrm{Ga}$, and $120 \mathrm{~K}$ at $2.0 \mathrm{Ga}$; with a secular cooling of the upper mantle by $75 \mathrm{~K}-100 \mathrm{~K}$ per $\mathrm{Ga}$ (Anderson, 2007; Hamilton, 2007a,b). Korenaga (2008) believes that such high mantle temperatures could present a problem for the emergence of plate tectonics prior to the Proterozoic.

Hamilton (2007a,b) shows that plate tectonic processes did not operate in the Archean, with some elements of plate tectonics beginning at $\sim 2.1 \mathrm{Ga}$, though they were quite distinct from the modern form, which began to operate only from Neoproterozoic or very early Paleozoic period. He links initiation of the present form of plate tectonics with the formation of ophiolites and ultra-high pressure rocks. Sharkov and Bogatikov (2001) also indicate that the onset of plate tectonics on Earth took place at 2.2-2.0 Ga.

Hamilton (2011) shows that Archean, Paleoproterozoic and Mesoproterozoic rocks, assemblages and structures greatly differ from each other and from modern ones; he indicates a lack of evidence for subduction and seafloor spreading in rocks of Mesoproterozoic age and older, while they are widespread in Phanerozoic terrains. He states that subduction began at $\sim 850 \mathrm{Ma}$, while fully modern platetectonic processes only started in the Ordovician. Stern $(2005,2007,2008)$ argues that criteria for the operation of plate tectonics includes ophiolites, blueschists, and ultra-high-pressure metamorphic belts, all of which predominantly appear after $\sim 1 \mathrm{Ga}$, which is the reason why modern style plate tectonics began at this time or later in the Neoproterozoic. Ophiolites are very rare before $\sim \mathrm{Ga}$, and they manifest two modes of lithospheric motion expected from subduction tectonics: seafloor spreading and obduction. However, if the appearance of UHP rocks was explained as processes only taking place at great depths in subduction zones (Ernst, 1971), then the absence of these rocks prior to $\sim 620 \mathrm{Ma}$ (Stern, 2005) would put in the question the existence of the subduction process at earlier time periods. On the other hand, obduction is the most well-known process of plate tectonics (e.g., Pilchin, 2015), and always includes the presence of serpentinized peridotites and ophiolites.

The process of obduction with a model of the following evolution of region is thoroughly discussed in Pilchin and Eppelbaum (2002) and two simplified models for obduction on continental margin (1), and parts of ocean plate onto itself (2) are presented in Figures 2 and 3, respectively. 


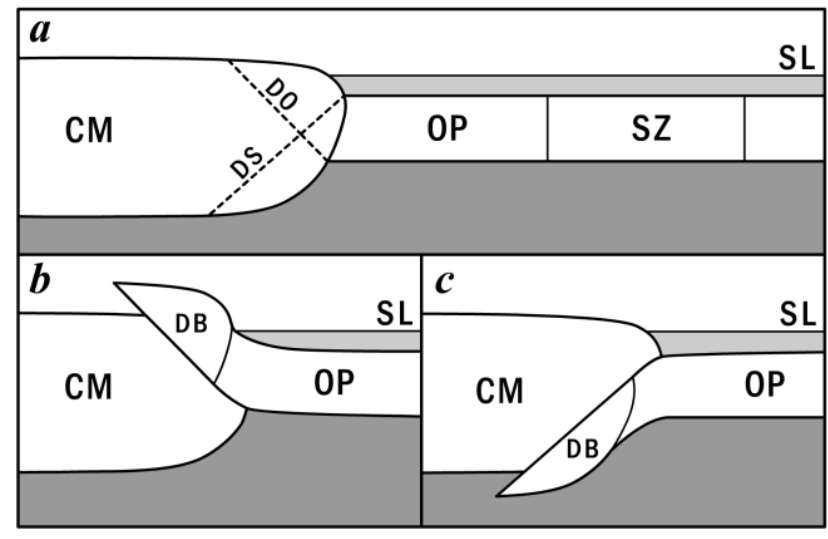

Fig. 2. Simplified diagram of tectonic activity of an oceanic plate near the continental margin caused by serpentinization within its peridotite layer: $a$ ) initial push of activated oceanic plate against the continental margin; $b$ ) formation of decollement and start of the obduction process; $c$ ) formation of the decollement and start of the subduction process. $\mathrm{CM}$ - continental margin; OP - oceanic plate; SZ - zone of serpentinization of peridotite layer of oceanic plate; SL - sea level; DO - possible position of decollement for starting the obduction process; DS possible position of decollement for starting the subduction process; DB - detached block of continental margin.

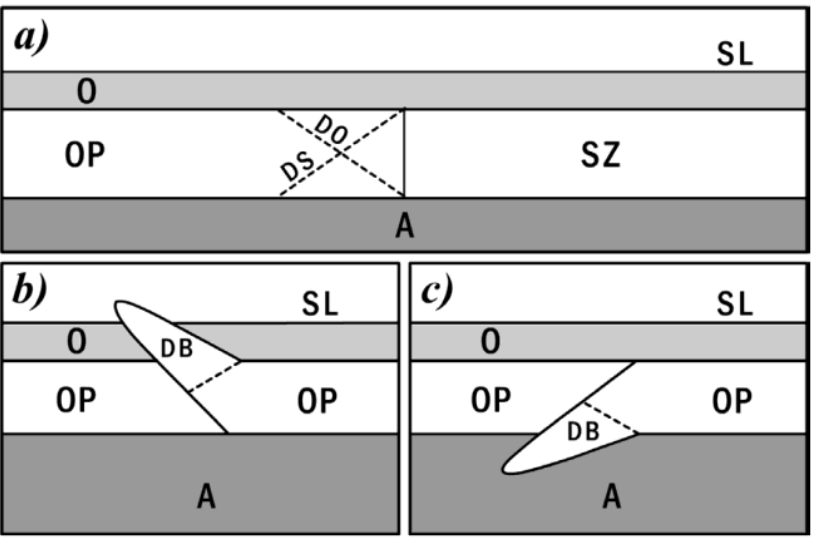

Fig. 3. Simplified diagram of tectonic activity of an oceanic plate in the oceanic areas caused by serpentinization within its peridotite layer. The designations are the same that in Fig. 2.

The aforementioned means that the absolute majority of ophiolites appearing only after $\sim 1 \mathrm{Ga}$ also creates problems explaining obduction processes at earlier time periods. Certain other researchers also note the scarcity of complete ophiolites before $1 \mathrm{Ga}$ (Condie and Kröner, 2008). Additionally, it is important to mention that blueschists (usually having age $\leq 800 \mathrm{Ma}$ (Stern, 2005), $\leq 1 \mathrm{Ga}$ (Condie and Kröner, 2008)) are always associated with ophiolites and serpentinite-containing thrusts (e.g., Pilchin, 2005), which is the main reason why they were chosen as one of the markers of the onset of plate tectonics. Stern (2005) indicates that plate tectonics could not have begun until the Earth cooled sufficiently. Davies (1992) shows that the corresponding cooling of the crust and upper mantle necessary for the onset of plate tectonics took place sometime between 0.9-1.4 Ga. He also notes that plate tectonics could have operated at earlier times, but more slowly.

The problem of plate tectonics emerging on Earth was thoroughly discussed at the Geological Society of America Penrose Conference in Lander, Wyoming, USA (June, 2006), where among others researchers came to the conclusion that "Earth is the only planet with plate tectonics, and it is controversial why and when this began. Some argue that plate tectonics already operated in Archean time, whereas others argue for a much later beginning... Demonstrating that plate tectonics operated at any given time requires evidence for subduction and independent plate motion and rotation. Understanding when and why plate tectonics began is one of the most important unresolved problems in understanding Earth..." (Stern, 2007; pp. 578-579). Reporting the discussions from this conference, Witze (2006) states that the 65 attendees came up with 18 different definitions of plate tectonics, with the majority voting that plate tectonics started between 3 billion and 4 billion years ago. Most researchers at this conference agreed on three components required for plate tectonics (Witze, 2006): (1) there must be rigid plates at the surface of the Earth; (2) those plates must move apart through ocean spreading with new crust being made where the sea floor pulls apart, and (3) the plates must dive on occasion beneath each other in subduction zones.

At the same time, researchers accepted subduction as a diagnostic factor for plate tectonics. However, the word "rigid" means "unbending," which as it was shown above could be a problem for the initiation of subduction. A rigid plate also means that it must be able to transfer applied force (pressure) to its other parts without altering its shape. This would require the plate to contain an elastic layer (elastic lithosphere) of significant thickness for the plate to operate as a single unit. The plate therefore could not be brittle, because it would then simply break apart before accomplishing the processes required for plate tectonics. We know that any typical lithospheric plate is composed of an upper brittle layer (with temperatures $<\sim 573 \mathrm{~K})$, an intermediate elastic lithosphere (with temperatures between $573 \mathrm{~K}$ and $873 \mathrm{~K}$ ), and a lower more plastic part of the lithosphere (with temperatures $>\sim 873 \mathrm{~K}$ ). It is indeed the elastic lithosphere that holds the plate together and provides necessary support for its operation as a single unit, so naturally a plate will be stronger when its elastic part is thicker. At the same time, a colder plate would have a thinner lower (plastic) part, which would also make the plate much 
stronger. This clearly indicates that thermodynamic conditions (primarily temperature conditions) of the surface and within the lithosphere are key parameters to the characteristics of lithospheric plates and their formation.

Let us take a look at the thermodynamic conditions of Earth's surface, and conditions of formation of the earliest lithosphere during the early Earth evolution. It was shown earlier (e.g., Pilchin and Eppelbaum, 2009; Eppelbaum et al., 2014; Pilchin, 2015) that after accretion of the Earth and other planets, the Moon and terrestrial planets were covered with a magma-ocean, which for Earth was $\sim 1000 \mathrm{~km}$ deep. This means that formation of the early Earth lithosphere, as well as that of any other planet, first began with solidification of the magma-ocean, and was strongly dependent on the rate of cooling of its surface and upper layers as it solidified (e.g., Pilchin and Eppelbaum, 2012). Formation of the early lithosphere in the Earth first began with the solidification of a forsterite layer at a depth of $70-100 \mathrm{~km}$ in Archean cratons within the magma-ocean (Pilchin, 2011; Pilchin and Eppelbaum, 2012).

The following features are among the best markers of the surface temperature conditions of early Earth: (1) drop of temperatures below $1173 \mathrm{~K}$ in the Hadean-Eoarchean during formation of zircons in the Jack Hills area (Yilgarn Craton, Western Australia); (2) formation of first Algoma-type banded iron formations (BIFs) as early as $3.85 \mathrm{Ga}$ in Greenland (Klein, 2005) and $3.5 \mathrm{Ga}$ in Australia (Klein, 2005), indicating a drop of surface temperatures below $843 \mathrm{~K}$; (3) temperatures dropping to $\sim 600 \mathrm{~K}$ at the time of the start of water-ocean formation at $~ 3.42-3.26 \mathrm{Ga}$ in Barberton GSB (South Africa) (Pilchin and Eppelbaum, 2012; Eppelbaum et al., 2014).

These temperature values clearly show that: formation of a brittle layer of lithosphere was not possible in the Hadean - Early Archean; no elastic layer of lithosphere could have been formed during the Hadean; the thin elastic lithosphere in the Early Archean began directly from the surface and had no contact with the convecting mantle. All this clearly demonstrates that the formation of strong rigid plates was not possible in the Hadean - Early Archean. It also means that plate tectonics did not operate on Earth during the Hadean - Early Archean. Analysis of conditions of the formation of granulites during different periods of the Archean and Early Proterozoic (Eppelbaum et al., 2014) reveals the following average temperatures:

This data indicates that crustal temperatures were relatively high at depths of the lower crust dur- ing the Early Archean - Early Proterozoic, and that the effective elastic thickness ( $T e$ ) of the continental lithosphere within Archean cratons during these periods of granulites formation was below $9-12 \mathrm{~km}$, with a total thickness of the young lithosphere of $\sim 100 \mathrm{~km}$ (e.g., Pilchin and Eppelbaum, 2012). Such high temperatures and such low effective elastic lithospheric thickness would force it to lose some or even most of its strength and rigidity, and consequently such lithospheric plates would not be able to participate in plate tectonic processes at this period (Pilchin and Eppelbaum, 2012). This is in agreement with data of Artyushkov et al. (2000) on the loss of lithospheric rigidity in areas with high temperatures and low effective elastic thickness.

Table 1

Averaged relationship between the age, temperature and depth of Earth's crustal blocks

\begin{tabular}{|l|c|c|}
\hline \multicolumn{1}{|c|}{ Age } & Temperature, K & $\begin{array}{c}\text { Depth, } \\
\mathrm{km}\end{array}$ \\
\hline Early and Middle Archean & 1059 & 30.3 \\
\hline Late Archean & 1127 & 30.0 \\
\hline Early Palaeoproterozoic & 1040 & 23 \\
\hline Late Palaeoproterozoic & 1087 & 28.4 \\
\hline
\end{tabular}

At the same time, for subduction to take place, crustal rocks must first be converted to dense eclogite to form the negative buoyancy force required (Pilchin, 2015). Analysis of the thermodynamic conditions of the formation of eclogites indicates that they were formed at average depths of $\sim 64 \mathrm{~km}$ (within the subcontinental lithospheric mantle) with average temperatures of 856 $\mathrm{K}$ and an average geothermal gradient of 9.1 $\mathrm{K} / \mathrm{km}$. This means that for the formation of eclogites through a basalt-eclogite phase transformation or other process involving the presence of crustal rocks, those rocks must first somehow be delivered to a depth of $\sim 64 \mathrm{~km}$ (e.g., Pilchin, 2015). It should also be stated that eclogites formed during the solidification of basaltic magma within magma chambers or magmatic channels would not form layers, especially not dense homogeneous layers, but rather eclogite pockets. It is also evident that the average temperature expected for eclogite formation at depths of $\sim 64 \mathrm{~km}$ is much lower than temperatures at shallower depths defined by conditions of granulite formation during the Early Archean - Early Proterozoic. Table 2 displays an analysis of thermodynamic conditions of the formation of eclogites at different temperatures (low, intermediate, and high temperatures). 
Thermodynamic conditions for the formation of eclogites with different origins (after Pilchin (2011), with modifications)

\begin{tabular}{|l|c|c|c|c|c|}
\hline $\begin{array}{c}\text { Eclogites Formed at Temper- } \\
\text { atures K, }(n)\end{array}$ & $\begin{array}{c}\text { Average } \\
T, \mathrm{~K}\end{array}$ & $\begin{array}{c}\text { Average } \\
P, \mathrm{GPa}\end{array}$ & $\begin{array}{c}\text { Average } \\
P / T^{*}, \\
\mathrm{MPa} / \mathrm{K}\end{array}$ & $\begin{array}{c}\text { Average Depth } \\
\text { of Lithostatic } \\
\text { Pressure, } \mathrm{km}\end{array}$ & $\begin{array}{c}\text { Average Geothermal } \\
\text { Gradient }(\mathrm{K} / \mathrm{km})\end{array}$ \\
\hline$T<843(n=279)$ & 762 & 1.51 & 3.10 & 50 & 9.8 \\
\hline $843<T<993(n=216)$ & 910 & 2.13 & 3.34 & 70 & 9.1 \\
\hline$T>993(n=61)$ & 1075.3 & 2.77 & 3.46 & 90 & 8.7 \\
\hline
\end{tabular}

*Average $P / T$ values were calculated as the average of the $P / T$ ratios

If we compare temperatures of the formation of eclogites (Table 2) with those of the formation of granulites at different periods of the Early Archean Early Proterozoic (Pilchin and Eppelbaum, 2012; Eppelbaum et al., 2014), it becomes clear that only high temperature eclogites (if any) could have been formed at depths greater than $30 \mathrm{~km}$; and the average depths of high-temperature eclogite formation are $\sim 90 \mathrm{~km}$. This means that crustal protoliths for the formation of eclogites during the Early Archean - Early Proterozoic would have to be delivered to an average depth of $\sim 90 \mathrm{~km}$ rather than $\sim 64 \mathrm{~km}$. This makes the problem even more complicated, because of the immensely gigantic force that would be required to push a plate/slab downwards to such an extent. Moreover, even though all kimberlites within cratonic areas of southern Africa contain eclogite (Gurney et al., 1991), it nonetheless remains a rare type of xenolith in most localities (Gurney et al., 1991; Pearson et al., 2003). Schulze (1989) concluded that the amount of eclogite in the upper $200 \mathrm{~km}$ of the subcontinental upper mantle is perhaps less than $1 \%$ by volume. Carlson et al. (2005) show that in general, high-velocity bodies consistent with large masses of eclogite are not observed in the continental mantle, and that at present eclogite appears to be a relatively minor component of the continental lithospheric mantle. At the same time, eclogites of Hadean - Early Archean age are completely unknown. All of the above means that during the Archean eclogite content within the subcontinental lithospheric mantle ranged from very low to negligible and could not play a significant role in generating conditions with negative buoyancy, and therefore the conventional subduction process was not possible.

Another problem that appeared with the onset of plate tectonics and subduction during early Earth evolution is related to the fact that the iron content of magmatic rocks in the Archean was the lowest, increasing towards the present time (Pilchin and Eppelbaum, 2008, 2009). Careful examination of magmatic rocks during most of Earth's evolution shows that mafic magmas in significant amounts only began to appear in continents from the Late Archean (Pilchin and Eppelbaum, 2008). The content of $\mathrm{FeO}$ (as total iron content) in mafic magmatic rocks in continents was $<10-11 \%$ in the Archean, $11.5-13.7 \%$ in the Proterozoic-Mesozoic and 12.25-14\% in the Tertiary (Pilchin and Eppelbaum, 2012). Additionally, the FeO-content of oceanic magmas is significantly lower, at about $8.3-9.1 \%$ for mid-ocean ridge basalts, $8.5-9.7 \%$ for island arc basalts, $10.2 \%$ for ocean floor basalts and 10.6-12.6\% for oceanic intraplate volcanism. While this means that continental rocks were less dense in the Archean, the low iron content in oceanic rocks also creates a density problem for the oceanic lithosphere, which would have been even more buoyant than continental rocks. This is a fundamental obstacle to the start of the subduction process for which negative buoyancy is crucial.

On other hand, the fact that water-ocean formation began only at the end of the Early Archean (at 3.26 Ga; Pilchin and Eppelbaum, 2012; Eppelbaum et al., 2014) means that during the Hadean - Early Archean, the oceanic lithosphere as we know did not exist, rendering the present form of plate tectonics impossible during these time periods. It also means that formation of the oceanic lithosphere started around the boundary between the Early and Middle Archean. It is difficult to pinpoint when the first oceanic lithosphere emerged on Earth, but we know that formation of obduction processes and the appearance of remnants of an oceanic peridotite layer on the surface started only in the Early Proterozoic (e.g., Pilchin, 2016b). In other words, formation of the oceanic lithosphere and the start of plate tectonic processes in the Earth took place a long time after the Early Archean.

To reiterate, the high surface temperatures, a mostly plastic lithosphere, the presence of magma layers at shallow depths, absence of a water-ocean and oceanic lithosphere, absence of eclogites, absence of serpentinites and many other mentioned above reasons made it impossible for plate tectonics to operate on Earth in Hadean - Early Archean.

Let us take a look at the possibility of plate tectonics operating on other planets of the Solar System during their early evolution. It is generally accepted that the Earth is the only known planet with subduction zones and plate tectonics (e.g., Stevenson, 1994; Stern, 2005, 2008). At the same time, some researchers believe that some form of plate tectonics could have oc- 
curred in the history of Mars and Venus (Sleep, 1994; Schubert et al., 2001; Fowler and O'Brien, 1996; Turcotte et al., 1999; Solomatov, 2004).

Dohm et al. (2015) hypothesize plate tectonics on Mars to have terminated sometime prior to the $\sim 4.0 \mathrm{Ga}$ Hellas impact events, which is referred to as the Mars plate-tectonic-basement hypothesis and includes the Claritas subduction zone region. The data points to a Hadean-age-equivalent phase of plate tectonism on Mars.

Pilchin (2016a) has shown that the region of Venus's accretion within the solar nebula was relatively hot $(750-850 \mathrm{~K})$, and that the planet was most likely able to collect more heat energy during accretion than Earth or Mars. Venus was under heavy bombardment during its early evolution, as any other planet, and received much more heat energy from the Sun than Earth or Mars, making it likely that Venus never had a surface temperature lower than it currently does ( $740 \mathrm{~K})$. This means that the Venusian surface never cooled below the temperature of water-ocean formation, and subsequently never had an oceanic lithosphere. It would also mean that its lithosphere never formed an elastic layer thicker than a few kilometers, which always ran from the surface. The plastic and molten rocks at shallow depths would not permit any plate to descend under such thermal conditions (Pilchin, 2015). It is of course too early to talk about plate tectonics on Venus, as it does not yet have thick elastic plates, nor has it yet cooled sufficiently to form rigid plates. However, the impossibility of a waterocean forming, not to mention an oceanic lithosphere, and the impossibility for the serpentinization process to take place makes Earth-type plate tectonics on Venus simply unimaginable in its future.

In the case of Mars, many researchers believe that a water-ocean has existed on the planet at some period (e.g., Carr, 1996; Clifford and Parker, 2001), with different researches proposing various sizes for it. Such an ocean may have contained a significant amount of water, estimated at a global equivalent layer (GEL) of $500-1000 \mathrm{~m}$ in the Late Hesperian Early Amazonian (Carr, 1996), and alternatively at a total GEL of $\sim 550-1400 \mathrm{~m}$ (Clifford and Parker, 2001). This means that the formation of an oceanic crust/lithosphere was possible in the past. This is in agreement with recent discoveries of serpentine on the Martian surface (e.g., Ehlmann et al., 2010) in mélange terrains of the Claritas Rise and the Nili Fossae, several southern highlands impact craters, and the regional olivine-rich stratigraphic unit near the Isidis basin. This evidence of the presence of serpentine is very important in analyzing the possibility of the existence of a Martian water-ocean, as well as that of plate tectonics having operated on the planet in its past, since on Earth the formation of serpentine is in- variably associated with the serpentinization process. That the presence of serpentine on Mars is uncommon (e.g., Ehlmann et al., 2010) means that serpentinization took place at some depth, and that the process was of a limited scale, preventing the evolution of thrust systems. The fact that serpentine is found in association with mélange terrains at the Claritas Rise and the Nili Fossae is unequivocal evidence that the serpentinization process did in fact take place on Mars, as the formation of mélanges is also typical for the serpentinization process on Earth (e.g., Pilchin, 2005). However, the presence of significant amounts of olivine on Mars (e.g., Ehlmann et al., 2010) indicates that serpentinization was not widely spread across the planet. It also suggests either a quick cooling of the planet's crust to below about 473-523 K, or a lack of water within the crust in contact with olivine. Ehlmann et al. (2010) come to the conclusion that serpentine-bearing materials appear to be restricted to Noachian-aged rocks in the Nili-Fossae olivinecarbonate-serpentine unit. Since it is clear that water was present on Mars in significant quantities, it is then likely that the temperature at some depths within the crust dropped below 473-523 K by the end of the Noachian. In which case, most of the crust would have been much colder than is required to form the elastic portion of the lithosphere, and it is possible that plates were then too thick to initiate plate tectonics. Moreover, the absence of $\mathrm{SO}_{2}$ from the present Martian atmosphere (e.g., Catling, 2004) indicates the lack of any significant volcanic activity for a long period of time. The abovementioned shows that Mars does not have the energy required for plate tectonics at this time, and its ensuing cooling hinders any expectations for plate tectonic processes in the planet's future.

Lastly, to briefly mention conditions on our nearest terrestrial neighbor. The presence of a 52km-thick (Taylor and McLennan, 2009) buoyant anorthosite crust on the Moon and a lack of energy sources indicate that plate tectonics was not possible there in the past, and nor will it take place there in the future. The enigmatic event proposed to have taken place on the Moon between 3.4-3.9 billion years ago (Pechersky and Eppelbaum, 2018) requires further study for possible connection with plate tectonic processes.

\section{Conclusions}

The review given here does not at all exhaust such a complex topic as the assessment of the mutual influence of plate tectonics and Earth evolution. It is multicomponent and intricately prolonged (over hundreds of millions of years). Due to the lack of sufficient space in the journal, some key processes of Earth's development preceding the start of plate tectonics were overlooked such as: 'Formation, evo- 
lution, and solidification of the magma-ocean', 'Problems relating to the Earth's primordial crust', 'Formation of overpressure', 'Eclogite problems' and others. Nevertheless, the authors hope that this study will contribute to a deeper understanding of these complex processes that have shaped the modern face of the Earth.

\section{REFERENCES}

Abramovich A.A. (Ed.). Methods of theoretical geology. Nedra. Leningrad, 1978, 335 p. (in Russian).

Aleinikov A.L., Belikov V.T., Eppelbaum L.V. Some physical foundations of geodynamics. Kedem Printing-House. Tel Aviv, Israel, 2001, 172 p. (in Russian).

Alvarez W. Geological evidence for the geographical pattern of mantle return flow and the driving mechanism of plate tectonics. Journ. of Geophysical Research, Vol. 87, No. B8, 1982, pp. 6697-6710.

Alvarez W. Geologic evidence for the plate-driving mechanism: The continental undertow hypothesis and the Australian-Antarctic discordance. Tectonics, Vol. 9, No. 5, 1990, pp.1213-1220.

Ampferer O. On the motion picture of fold mountains. Yearbook of the Imperial and Royal geological institute. Vol. 56, 1906, pp. 539-622 (in German).

Ampferer O., Hammer W. Geological cross-section through the Eastern Alps from Allga'u to the Lake Garda. Jahrb. Geol. Reichsanstalt, Vol. 61, Nos. 3-4, 1911, pp. 531-710 (in German).

Amstutz A. On the evolution of Alpine structures. Archives Sci., Vol. 4, No. 5, 1951, pp. 323-329 (in French).

Anderson D.L. Theory of the Earth. Blackwell Scientific Publ. Boston, USA, 1989, $366 \mathrm{p}$.

Anderson D.L. Top-Down tectonics? Science, Vol. 293, 2001, pp. 2016-2018.

Anderson D.L. Plate tectonics as a far- from- equilibrium selforganized system. In: (Stein S. and Freymueller J.T. Eds.) Plate boundary zones. Geodynamics series 30, the American Geophysical Union, Geophys. Monograph, Washington, DC, 2002, pp. 411-425.

Anderson D.L. New theory of the Earth. Cambridge Univ. Press. $2^{\text {nd }}$ ed., NY, USA, 2007, $400 \mathrm{p}$.

Anderson D.L., Tanimoto T., Zhang Y.S. Plate tectonics and hotspots: the third dimension. Science, Vol. 256, No. 5064, 1992, pp.1645-1651.

Arndt N.T. and Nisbet E.G. Processes on the young Earth and the habitats of early life. Annual Rev. of Earth Planetary Sci., Vol. 40, 2012, pp. 521-549.

Artyushkov E.V., Mörner N.A., Tarling D.H. The cause of loss of lithospheric rigidity in areas far from plate tectonic activity. Geophysical Jour. International, Vol. 143, No. 3, 2000, pp. 752-776.

Bell E.A. Hadean-Archean transitions: Constraints from the Jack Hills detrital zircon record. Ph.D. thesis, University of California, Los Angeles, 2013, 299 p.

Belousov V.V. The Foundations of geotectonics. Nedra. Moscow, 1975, 264 p. (in Russian).

Bénard H. Cellular eddies in a liquid slick. General Review of Pure and Applied Sciences, Vol. 11, 1900, pp. 1261-1271 and 1309-1328 (in French).

Bénard $\mathrm{H}$. Cell vortices in a liquid sheet transporting heat by steady-state convection. Ann. Chem. Phys., Series 7, Vol. 23, 1901, pp. 62-144 (in French).

Benioff H. Seismic evidence for the fault origin of oceanic deeps. Bull. of the Geol. Society of America, Vol. 60, 1949 , pp. $1837-1866$.

\section{Dedication}

Dr. Arkady Pilchin (1951-2016) was passionate about passing his understanding, unique perspectives, and methods of inquiry to future generations of geoscientists. His seminal contributions to different branches of Geophysics and Earth and Planetary Sciences continue to shine in our field of study.

\section{ЛИТЕРАТУРА}

Alvarez W. Geological evidence for the geographical pattern of mantle return flow and the driving mechanism of plate tectonics. Journ. of Geophysical Research, Vol. 87, No. B8, 1982, pp. 6697-6710.

Alvarez W. Geologic evidence for the plate-driving mechanism: The continental undertow hypothesis and the Australian-Antarctic discordance. Tectonics, Vol. 9, No. 5, 1990, pp. 1213-1220.

Anderson D.L. Theory of the Earth. Blackwell Scientific Publ. Boston, USA, 1989, $366 \mathrm{p}$.

Anderson D.L. Top-Down tectonics? Science, Vol. 293, 2001, pp. 2016-2018.

Anderson D.L. Plate tectonics as a far- from- equilibrium selforganized system. In: (Stein S. and Freymueller J.T. Eds.) Plate boundary zones. Geodynamics series 30, the American Geophysical Union, Geophys. Monograph, Washington, DC, 2002, pp. 411-425.

Anderson D.L. New theory of the Earth. Cambridge Univ. Press. $2^{\text {nd }}$ ed., NY, USA, 2007, $400 \mathrm{p}$.

Anderson D.L., Tanimoto T., Zhang Y.S. Plate tectonics and hotspots: the third dimension. Science, Vol. 256, No. 5064, 1992, pp.1645-1651.

Arndt N.T. and Nisbet E.G. Processes on the young Earth and the habitats of early life. Annual Rev. of Earth Planetary Sci., Vol. 40, 2012, pp. 521-549.

Artyushkov E.V., Mörner N.A., Tarling D.H. The cause of loss of lithospheric rigidity in areas far from plate tectonic activity. Geophysical Jour. International, Vol. 143, No. 3, 2000, pp. 752-776.

Bell E.A. Hadean-Archean transitions: Constraints from the Jack Hills detrital zircon record. Ph.D. thesis, University of California, Los Angeles, 2013, 299 p.

Benioff H. Seismic evidence for the fault origin of oceanic deeps. Bull. of the Geol. Society of America, Vol. 60, 1949, pp. 1837-1866.

Benioff $\mathrm{H}$. Orogenesis and deep crustal structure - Additional evidence from seismology. Bull. of the Geol. Society of America, Vol. 65, 1954, pp. 385-400.

Bercovici D. The generation of plate tectonics from mantle convection. Earth and Planet. Science Lett., Vol. 205, No. 3-4, 2003, pp. 107-121.

Bercovici D. Mantle convection. In: (Gupta H.K., Ed.), Encyclopedia of Solid Earth Geophysics, Springer. 2011, pp. 832-851.

Bercovici D., Ricard Y., Richards M.A. The relation between mantle dynamics and plate tectonics: A primer. In: (Richards, M., Gordon, R. and van der Hilst, R., Eds.), The history and dynamics of global plate motions. Geophys. Monograph 121, American Geophysical Union, 2000, pp. 5-46.

Bina C.R., Stein S., Marton F.C., Van Ark E.M. Implications of slab mineralogy for subduction dynamics. Physics of the Earth and Planet. Interiors, Vol. 127, No. 1-4, 2001, pp. 51-66.

Bindeman I.N., Eiler J.M., Wing B.A., Farquhar J. Rare sulfur and triple oxygen isotope geochemistry of volcanogenic 
Benioff H. Orogenesis and deep crustal structure - Additional evidence from seismology. Bull. of the Geol. Society of America, Vol. 65, 1954, pp. 385-400.

Bercovici D. The generation of plate tectonics from mantle convection. Earth and Planet. Science Lett., Vol. 205, No. 3-4, 2003, pp. 107-121.

Bercovici D. Mantle convection. In: (Gupta H.K., Ed.) Encyclopedia of Solid Earth Geophysics, Springer. 2011, pp. 832-851.

Bercovici D., Ricard Y., Richards M.A. The relation between mantle dynamics and plate tectonics: A primer. In: (Richards, M., Gordon, R., van der Hilst, R., Eds.), The history and dynamics of global plate motions. Geophys. Monograph 121, American Geophysical Union, 2000, pp. 5-46.

Bina C.R., Stein S., Marton F.C., Van Ark E.M. Implications of slab mineralogy for subduction dynamics. Physics of the Earth and Planet. Interiors, Vol. 127, No. 1-4, 2001, pp. 51-66.

Bindeman I.N., Eiler J.M., Wing B.A., Farquhar J. Rare sulfur and triple oxygen isotope geochemistry of volcanogenic sulfate aerosols. Geochim. et Cosmochim. Acta, Vol. 71, No. 9, 2007, pp. 2326-2343.

Bird P. Testing hypotheses on plate-driving mechanisms with global lithosphere models including topography, thermal structure, and faults. Journ. of Geophysical Research, Vol.103, No. B5, 1998, pp.10115-10129.

Bokelmann G.H.R. Which forces drive North America? Geology, Vol. 30, No. 11, 2002, pp.1027-1030.

Bott M.H.P. Modeling the plate-driving mechanism. Journ. of the Geological Society, Vol. 150, No. 5, 1993, pp. 941-951.

Buiter S.J.H., Govers R., Wortel M.J.R. A modelling study of vertical surface displacements at convergent plate margins. Geophys. Jour. Intern., Vol. 147, 2001, pp. 415-427.

Bull A.J. A hypothesis of mountain building. Geol. Magazine, Vol. 58, 2001, pp. 364-367.

Burke K. Plate tectonics, the Wilson cycle, and mantle plumes: geodynamics from the top. Ann. Review of Earth and Planetary Sci., Vol. 39, No. 1, 2011, pp. 1-29.

Calvert A.J., Sawyer E.W., Davis W.J., Ludden J.N. Archean subduction inferred from seismic images of a mantle suture in the Superior Province. Nature, Vol. 375, No. 6533, 1995, pp. 670-674.

Carlson R.L. Boundary forces and plate velocities. Geophysical Research Lett., Vol. 8, 1981, pp. 958-961.

Carlson R.W., Pearson D.G., James D.E. Physical, chemical and chronological characteristics of continental mantle. Reviews of Geophysics, Vol. 43, RG1001, 2005, pp.1-24.

Carr M.H. Water on Mars. Oxford Univ. Press. N.Y., USA, 1996, $197 \mathrm{p}$.

Cartwright N. How the laws of physics lie. Oxford University Press. Oxford, UK, 1983, 230 p.

Catling D. Atmospheric evolution of Mars. In: Encyclopedia of Paleoclimatology and Ancient Environments. Kluwer Acad. Publisher. 2004, pp.1-16.

Cawood P.A., Kröner A., Pisarevsky S. Precambrian plate tectonics: Criteria and evidence. Geol. Soc. of Amer. Today, Vol. 16, No. 7, 2006, pp. 4-11.

Chapple W.M., Tullis T.E. Evaluation of the forces that drive the plates. Journ. of Geophysical Research, Vol. 82, 1977, pp. 1967-1984.

Chase C.G. Extension behind island arcs and motions relative to hot spots. Journ. of Geophysical Research, Vol. 83, No. B11, 1978, pp .5385-5387.

Clayton R.N., O’Neil J.R., Mayeda T.K. Oxygen isotope exchange between quartz and water. Journ. of Geoph. Research, Vol. 77, No. 17, 1972, pp. 3057-3066.

Clifford S.M., Parker T.J. The evolution of the Martian hydrosphere: implications for the fate of a primordial ocean and the current state of the northern plains. Icarus, Vol. 154, 2001, pp. 40-79. sulfate aerosols. Geochim. et Cosmochim. Acta, Vol. 71, No. 9, 2007, pp. 2326-2343.

Bird P. Testing hypotheses on plate-driving mechanisms with global lithosphere models including topography, thermal structure, and faults. Journ. of Geophysical Research, Vol.103, No. B5, 1998, pp. 10115-10129.

Bokelmann G.H.R. Which forces drive North America? Geology, Vol. 30, No. 11, 2002, pp.1027-1030.

Bott M.H.P. Modeling the plate-driving mechanism. Journ. of the Geological Society, Vol. 150, No. 5, 1993, pp. 941-951.

Buiter S.J.H., Govers R., Wortel M.J.R. A modelling study of vertical surface displacements at convergent plate margins. Geophys. Jour. Intern., Vol. 147, 2001, pp. 415-427.

Bull A.J. A hypothesis of mountain building. Geol. Magazine, Vol. 58, 2001, pp. 364-367.

Burke K. Plate tectonics, the Wilson cycle, and mantle plumes: geodynamics from the top. Ann. Review of Earth and Planetary Sci., Vol. 39, No. 1, 2011, pp. 1-29.

Calvert A.J., Sawyer E.W., Davis W.J., Ludden J.N. Archean subduction inferred from seismic images of a mantle suture in the Superior Province. Nature, Vol. 375, No. 6533,1995, pp. 670-674.

Carlson R.L. Boundary forces and plate velocities. Geophysical Research Lett., Vol. 8, 1981, pp. 958-961.

Carlson R.W., Pearson D.G., James D.E. Physical, chemical and chronological characteristics of continental mantle. Reviews of Geophysics, Vol. 43, RG1001, 2005, pp. 1-24.

Carr M.H. Water on Mars. Oxford Univ. Press. N.Y., USA, 1996, $197 \mathrm{p}$.

Cartwright N. How the laws of physics lie. Oxford University Press. Oxford, UK, 1983, 230 p.

Catling D. Atmospheric evolution of Mars. In: Encyclopedia of Paleoclimatology and Ancient Environments. Kluwer Acad. Publisher. 2004, pp.1-16.

Cawood P.A., Kröner A., Pisarevsky S. Precambrian plate tectonics: Criteria and evidence. Geol. Soc. of Amer. Today, Vol. 16, No. 7, 2006, pp. 4-11.

Chapple W.M., Tullis T.E. Evaluation of the forces that drive the plates. Journ. of Geophysical Research, Vol. 82, 1977, pp. 1967-1984.

Chase C.G. Extension behind island arcs and motions relative to hot spots. Journ. of Geophysical Research, Vol. 83, No. B11, 1978, pp .5385-5387.

Clayton R.N., O’Neil J.R., Mayeda T.K. Oxygen isotope exchange between quartz and water. Journ. of Geoph. Research, Vol. 77, No. 17, 1972, pp. 3057-3066.

Clifford S.M., Parker T.J. The evolution of the Martian hydrosphere: implications for the fate of a primordial ocean and the current state of the northern plains. Icarus, Vol. 154, 2001, pp. 40-79.

Cloetingh S., Wortel R. Stress in the Indo-Australian plate. Tectonophysics, Vol. 132, No. 1-3, 1986, pp. 49-67.

Cogné J.P., Humler E., Courtillot V. Mean age of oceanic lithosphere drives eustatic sea-level change since Pangea breakup. Earth and Planetary Sci. Lett., Vol. 245, 2006, pp. 115-122.

Condie K.C. Benioff zone. In: Encyclopedia of Earth Science, Structural Geology and Tectonics, 1987, pp. 29-33.

Condie K.C. Origin of the Earth's crust. Global and Planetary Change, Vol. 1, No. 1-2, 1989, pp. 57-81.

Condie K.C., Kröner A. When did plate tectonics begin? Evidence from the geologic record. In: (Condie, K.C. and Pease, V., Eds.), When did plate tectonics begin on planet Earth? Geol. Soc. of Amer. Bull., Vol. 440, 2008, pp. 281-294.

Conrad C.P., Lithgow-Bertelloni C. How mantle slabs drive plate tectonics. Science, Vol. 298, No. 5591, pp. 207-209.

Cox A. Plate tectonics and geomagnetic reversals. W.H.Freeman and Co publishers. US, 1973, $702 \mathrm{p}$. 
Cloetingh S., Wortel R. Stress in the Indo-Australian plate. Tectonophysics, Vol. 132, No.1-3, 1986, pp. 49-67.

Cogné J.P., Humler E., Courtillot V. Mean age of oceanic lithosphere drives eustatic sea-level change since Pangea breakup. Earth and Planetary Sci. Lett., Vol. 245, 2006, pp. 115-122.

Condie K.C. Benioff zone. In: Encyclopedia of Earth Science, Structural Geology and Tectonics, 1987, pp. 29-33.

Condie K.C. Origin of the Earth's crust. Global and Planetary Change, Vol. 1, No. 1-2, 1989, pp. 57-81.

Condie K.C., Kröner A. When did plate tectonics begin? Evidence from the geologic record. In: (Condie K.C., Pease V., Eds.) When did plate tectonics begin on planet Earth? Geol. Soc. of Amer. Bull., Vol. 440, 2008, pp. 281-294.

Conrad C.P., Lithgow-Bertelloni C. How mantle slabs drive plate tectonics. Science, Vol. 298, No. 5591, pp. 207-209.

Cox A. Plate tectonics and geomagnetic reversals. W.H.Freeman and Co publishers. US, 1973, $702 \mathrm{p}$.

Cox A., Hart R.B. Plate tectonics: how it works. WileyBlackwell publications. 1986, $392 \mathrm{p}$.

Cruciani C., Carminati E., Doglioni C. Slab dip vs. lithosphere age: no direct function. Earth and Planetary Science Lett., Vol. 238, No. 3-4, 2005, pp. 298-310.

Daly R.A. Geology of the North American Cordillera at the forty-ninth parallel. Canada Geol. Survey Mem., Vol. 38, 1912, p. 481; pp. 489-490; p. 570; pp. 572-573.

Dana J.D. 1873. On some results of the Earth's contraction from cooling, including a discussion of the origin of mountains and the nature of the Earth's interior. Amer. Journ. of Sci., Vol. 5, pp. 423-443; V. 6, pp. 6-14; pp.104-115; pp. 161-172.

Davies G.F. Thermal histories of convective earth models and constraints on radiogenic heat production in the Earth. Journ. of Geophys. Research, Vol. 85, No. B5, 1980, pp. 2517-2530.

Davies G.F. On the emergence of plate tectonics. Geology, Vol. 20, 1992, pp. 963-966.

Davies G.F. Dynamic Earth: plates, plumes and mantle convection. Cambridge Univ. Press. Cambridge, UK. 1999, 458 p.

Davies G.F. Mantle convection for geologists. Cambridge Univ. Press. New York, USA, 2011, 232 p.

Dewey J.F. Lithospheric stress, deformation, and tectonic cycles: the disruption of Pangaea and the closure of Tethys. Geological Society, London, Special Publications, Vol. 37, 1988, 23-40.

de Wit M.J. On Archean granites, greenstones, cratons and tectonics: Does the evidence demand a verdict? Precambrian Research, Vol. 91, 1998, pp.181-226.

Dietz R.S. Continent and ocean basin evolution by spreading of the sea floor. Nature, 190, 1961, pp. 854-857.

Dohm J.M., Spagnuolo M.G., Williams J.-P., Viviano-Beck C.E., Karunatillake S., Álvarez O., Anderson R.C., Miyamoto H., Baker V.R., Fairén A., Mahaney W.C., Hare T.M., Robbins S.J., Niihara T., Yin A., Judice T., Olsen N., Maruyama S. The Mars plate tectonic - basement hypothesis. 46th Lunar and Planetary Science Conference, held March 16-20, 2015 in The Woodlands, Texas. LPI Contribution No. 1832, 2015, p.1741.

Ducea M.N., Saleeby J. Trace element enrichment signatures by slab-derived carbonate fluids in the continental mantle wedge: an example from the Sierra Nevada, California. Trans. of the Ann. Meet. of the Geol. Soc. of America, Seattle, Vol. 35, No. 6, 2003, p. 138.

Dunlop D.J. Continuous and stepwise thermal demagnetization: are they equivalent? Geophys. Journ. Intern., Vol. 177, No. 3, 2009, pp. 949-957.

Ehlmann B.L., Mustard J.F., Murchie S.L. Geologic setting of serpentine deposits on Mars. Geophysical Research Lett., V. 37, L06201, 2010, pp. 1-5.
Cox A., Hart R.B. Plate tectonics: how it works. WileyBlackwell publications. 1986, $392 \mathrm{p}$.

Cruciani C., Carminati E., Doglioni C. Slab dip vs. lithosphere age: no direct function. Earth and Planetary Science Lett., Vol. 238, No. 3-4, 2005, pp. 298-310.

Daly R.A. Geology of the North American Cordillera at the Forty-Ninth Parallel. Canada Geol. Survey Mem., Vol. 38, 1912, p. 481; pp. 489-490; p. 570; pp. 572-573.

Dana J.D. 1873. On some results of the Earth's contraction from cooling, including a discussion of the origin of mountains and the nature of the Earth's interior. Amer. Jour. of Sci., Vol. 5, pp. 423-443; Vol. 6, pp. 6-14; pp. 104-115; pp. 161-172.

Davies G.F. Thermal histories of convective earth models and constraints on radiogenic heat production in the Earth. Journ. of Geophys. Research, Vol. 85, No. B5, 1980, pp. 2517-2530.

Davies G.F. On the emergence of plate tectonics. Geology, Vol. 20, 1992, pp. 963-966.

Davies G.F. Dynamic Earth: plates, plumes and mantle convection. Cambridge Univ. Press. Cambridge, UK. 1999, 458 p.

Davies G.F. Mantle convection for geologists. Cambridge Univ. Press. New York, USA, 2011, 232 p.

Dewey J.F. Lithospheric stress, deformation, and tectonic cycles: the disruption of Pangaea and the closure of Tethys. Geological Society, London, Special Publications, Vol. 37, $1988,23-40$.

de Wit M.J. On Archean granites, greenstones, cratons and tectonics: Does the evidence demand a verdict? Precambrian Research, Vol. 91, 1998, pp.181-226.

Dietz R.S. Continent and ocean basin evolution by spreading of the sea floor. Nature, 190, 1961, pp. 854-857.

Dohm J.M., Spagnuolo M.G., Williams J.-P., Viviano-Beck C.E., Karunatillake S., Álvarez O., Anderson R.C., Miyamoto H., Baker V.R., Fairén A., Mahaney W.C., Hare T.M., Robbins S.J., Niihara T., Yin A., Judice T., Olsen N., Maruyama S. The Mars plate tectonic - basement hypothesis. 46th Lunar and Planetary Science Conference, held March 16-20, 2015 in The Woodlands, Texas. LPI Contribution No. 1832, 2015, p.1741.

Ducea M.N., Saleeby J. Trace element enrichment signatures by slab-derived carbonate fluids in the continental mantle wedge: an example from the Sierra Nevada, California. Trans. of the Ann. Meet. of the Geol. Soc. of America, Seattle, Vol. 35, No. 6, 2003, p. 138.

Dunlop D.J. Continuous and stepwise thermal demagnetization: are they equivalent? Geophys. Jour. Intern., Vol. 177, No. 3, 2009, pp. 949-957.

Ehlmann B.L., Mustard J.F., Murchie S.L. Geologic setting of serpentine deposits on Mars. Geophysical Research Lett., V. 37, L06201, 2010, pp. 1-5.

Elsasser W.M. Convection and stress propagation in the upper mantle. Princeton University Technical Report, Vol. 5, 1967, $130 \mathrm{p}$.

Elsasser W.M. Convection and stress propagation in the upper mantle. In: (Runcorn, S. K. Ed.) The application of modern physics to the Earth and planetary interiors. WileyInterscience, New York, 1969, pp. 223-246.

Elsasser W.M. Sea-floor spreading as thermal convection. Journ. of Geophysical Research, Vol. 76, No. 5, 1971, pp. 1101-1112.

Eppelbaum L.V. Comparison of 3D integrated geophysical modeling in the South Caucasian and Eastern Mediterranean segments of the Alpine-Himalayan tectonic belt. Azerb. Nation. Academy of Sci. Proceedings. The Sciences of Earth, No. 3, 2015, pp. 25-45.

Eppelbaum L.V., Ben-Avraham Z., Katz Y., Cloetingh S., Kaban M. Combined multifactor evidence of a Giant LowerMantle Ring Structure below the Eastern Mediterranean. Positioning, Vol. 11, 2020, pp. 11-32. 
Elsasser W.M. Convection and stress propagation in the upper mantle. Princeton University Technical Report, Vol. 5, 1967, $130 \mathrm{p}$.

Elsasser W.M. Convection and stress propagation in the upper mantle. In: (Runcorn, S. K. Ed.) The application of modern physics to the Earth and planetary interiors. WileyInterscience. New York, 1969, pp. 223-246.

Elsasser W.M. Sea-floor spreading as thermal convection. Journ. of Geophysical Research, Vol. 76, No. 5, 1971, pp. 1101-1112.

Eppelbaum L.V. Multimodel approach to the study of geophysical targets. Deposited by VINITI, USSR Academy of Sciences, No. 7842-87, 1987, pp.1-10 (in Russian).

Eppelbaum L.V. Comparison of 3D integrated geophysical modeling in the South Caucasian and Eastern Mediterranean segments of the Alpine-Himalayan tectonic belt. Azerb. Nation. Academy of Sci. Proceedings. The Sciences of Earth, No. 3, 2015, pp. 25-45.

Eppelbaum L.V., Ben-Avraham Z., Katz Y., Cloetingh S., Kaban M. Combined multifactor evidence of a Giant LowerMantle Ring Structure below the Eastern Mediterranean. Positioning, Vol. 11, 2020, pp. 11-32.

Eppelbaum L., Isakov A. Implementation of the geocorrelation methodology for predictability of catastrophic weather events: long-term US tornado season and short-term hurricanes. Environmental Earth Sciences, Vol. 74, 2015, pp. 3371-3383.

Eppelbaum L.V., Katz Yu.I. Eastern Mediterranean: Combined geological-geophysical zonation and paleogeodynamics of the Mesozoic and Cenozoic structuralsedimentation stages. Marine and Petroleum Geology, Vol. 65, 2015a, pp. 198-216.

Eppelbaum L.V., Katz Yu.I. Paleomagnetic mapping in various areas of the Easternmost Mediterranean based on an integrated geological-geophysical analysis. In: (Eppelbaum L., Ed.) New Developments in Paleomagnetism Research, Ser: Earth Sciences in the 21st Century. Nova Science Publisher. NY, 2015b, pp.15-52.

Eppelbaum L., Katz Yu. Significant tectono-geophysical features of the African-Arabian tectonic region: An overview. Geotectonics, Vol. 54, No. 2, 2020, pp. 266-283.

Eppelbaum L., Kutasov I., Pilchin A. Applied geothermics. Springer. Heidelberg - N.Y., 2014, $751 \mathrm{p}$.

Eppelbaum L.V., Nikolaev A.V., Katz Y.I. Space location of the Kiama paleomagnetic hyperzone of inverse polarity in the crust of the eastern Mediterranean. Doklady Earth Sciences (Springer), Vol. 457, No. 6, 2014, pp. 710-714.

Ernst W.G. Do mineral parageneses reflect unusually highpressure conditions of Franciscan metamorphism? Amer. Jour. of Science, Vol. 270, 1971, pp. 81-108.

Ernst W.G. Archean plate tectonics, rise of Proterozoic supercontinentality and onset of regional, episodic stagnant-lid behavior. Gondwana Research, Vol. 15, No. 3-4, 2009, pp. 243-253.

Fehlhaber K., Bird D.K. Oxygen-isotope exchange and mineral alteration in gabbros of the Lower Layered Series, Kap Edvard Holm Complex, East Greenland. Geology, Vol. 19, No. 8, 1991, pp. 819-822.

Fisher O. On the possibility of changes in the latitudes of places on the Earth's surface: being an appeal to physicists. Geological Magazine, Vol. 5, No. 7, 1878, pp. 291-297.

Fisher O. Physics of the Earth's crust. Macmillan and Co. London, UK, 1881, $391 \mathrm{p}$.

Foley B.J., Bercovici D., Elkins-Tanton L.T. Initiation of plate tectonics from post-magma ocean thermo-chemical convection. Journal of Geophysical Research: Solid Earth, V. 119, No. 11, 2014, pp. 8538-8561.

Fowler A.C., O'Brien S.B.G. A mechanism for episodic subduction on Venus. Journ. of Geophysical Research, Vol. 101, 1996, pp. 4755-4763.
Eppelbaum, L., Isakov A. Implementation of the geo-correlation methodology for predictability of catastrophic weather events: long-term US tornado season and short-term hurricanes. Environmental Earth Sciences, Vol. 74, 2015, pp. 3371-3383.

Eppelbaum L.V., Katz Yu.I. Eastern Mediterranean: Combined geological-geophysical zonation and paleogeodynamics of the Mesozoic and Cenozoic structuralsedimentation stages. Marine and Petroleum Geology, Vol. 65, 2015a, pp. 198-216.

Eppelbaum L.V., Katz Yu.I. Paleomagnetic mapping in various areas of the Easternmost Mediterranean based on an integrated geological-geophysical analysis. In: (Eppelbaum L., Ed.), New Developments in Paleomagnetism Research, Ser: Earth Sciences in the 21st Century. Nova Science Publisher. NY, 2015b, pp.15-52.

Eppelbaum L., Katz Yu. Significant tectono-geophysical features of the African-Arabian tectonic region: An overview. Geotectonics, Vol. 54, No. 2, 2020, pp. 266-283.

Eppelbaum L., Kutasov I., Pilchin A. Applied geothermics. Springer. Heidelberg - N.Y., 2014, 751 p.

Eppelbaum L.V., Nikolaev A.V., Katz Y.I. Space location of the Kiama paleomagnetic hyperzone of inverse polarity in the crust of the eastern Mediterranean. Doklady Earth Sciences (Springer), Vol. 457, No. 6, 2014, pp. 710-714.

Ernst W.G. Do mineral parageneses reflect unusually highpressure conditions of Franciscan metamorphism? Amer. Jour. of Science, Vol. 270, 1971, pp. 81-108.

Ernst W.G. Archean plate tectonics, rise of Proterozoic supercontinentality and onset of regional, episodic stagnant-lid behavior. Gondwana Research, Vol. 15, No. 3-4, 2009, pp. 243-253.

Fehlhaber K., Bird D.K. Oxygen-isotope exchange and mineral alteration in gabbros of the Lower Layered Series, Kap Edvard Holm Complex, East Greenland. Geology, Vol. 19, No. 8, 1991, pp. 819-822.

Fisher $\mathrm{O}$. On the possibility of changes in the latitudes of places on the Earth's surface: being an appeal to physicists. Geological Magazine, Vol. 5, No. 7, 1878, pp. 291-297.

Fisher O. Physics of the Earth's crust. Macmillan and Co. London, UK, 1881, $391 \mathrm{p}$.

Foley B.J., Bercovici D., Elkins-Tanton L.T. Initiation of plate tectonics from post-magma ocean thermo-chemical convection. Journal of Geophysical Research: Solid Earth, V. 119, No. 11, 2014, pp. 8538-8561.

Fowler A.C., O'Brien S.B.G. A mechanism for episodic subduction on Venus. Journ. of Geophysical Research, Vol. 101, 1996, pp. 4755-4763.

Frank B.Taylor. American geologist. Encyclopædia Britannica, 2015.

Frankel H.R. The continental drift controversy, V. 1: Wegener and the early debate. Cambridge Univ. Press. Cambridge, UK, 2012, $625 \mathrm{p}$.

Forsyth D., Uyeda S. On the relative importance of the driving forces of plate motion. Geophys. J. R. Astr. Soc., Vol. 43, 1975, pp. 163-200.

Gallagher V., Feely M., Högelsberger H., Jenkin G.R.T., Fallick A.E. Geological, fluid inclusion and stable isotope studies of Mo mineralisation, Galway Granite, Ireland. Mineral. Deposita, Vol. 27, 1992, pp. 314-325.

Glen W. The origins and early trajectory of the mantle plume quasi-paradigm. In: (Foulger G.R., Natland J.N., Presnal D.C., Anderson D.L., Eds.), Plates, plumes, and paradigms. The Geological Society of America Spec. volume 388, The Geol. Society of America, Boulder, Colorado, USA, 2005, pp. 91-117.

Gnibidenko H.S., Shashkin K.S. Basic principles of the geosynclinal theory. Tectonophysics, Vol. 9, No. 1, 1970, pp. 5-13. 
Frank B.Taylor. American geologist. Encyclopædia Britannica, 2015.

Frankel H.R. The continental drift controversy, V. 1: Wegener and the early debate. Cambridge Univ. Press. Cambridge, UK, 2012, $625 \mathrm{p}$.

Frolov V.T. On the science geology (paper 3). Moscow Univ Bull., Ser. 4: Geology, No.1, 2002, pp. 6-14 (in Russian).

Forsyth D., Uyeda S. On the relative importance of the driving forces of plate motion. Geophys. J. R. Astr. Soc., Vol. 43, 1975, pp. 163-200.

Gallagher V., Feely M., Högelsberger H., Jenkin G.R.T., Fallick A.E. Geological, fluid inclusion and stable isotope studies of Mo mineralisation, Galway Granite, Ireland. Mineral. Deposita, Vol. 27, 1992, pp. 314-325.

Glen W. The origins and early trajectory of the mantle plume quasiparadigm. In: (Foulger G.R., Natland J.N., Presnal D.C., Anderson D.L., Eds.) Plates, plumes, and paradigms. The Geological Society of America Spec. volume 388, The Geol. Society of America, Boulder, Colorado, USA, 2005, pp. 91-117.

Gnibidenko H.S., Shashkin K.S. Basic principles of the geosynclinal theory. Tectonophysics, Vol. 9, No. 1, 1970, pp. 5-13.

Grotzinger J.P., Kasting J.F. New constraints on Precambrian ocean composition. The Journal of Geology, Vol. 101, 1993, pp. 235-243.

Grove T.L., Parman S. Thermal evolution of the Earth as recorded by komatiites. Earth Planet. Sci. Lett., Vol. 219, 2004, pp. 173-187.

Gurney J.J., Moore R.O., Otter M.L., Kirkley M.B., Hops J.J., McCandless T.E. Southern African kimberlites and their xenoliths. In: (Kampunzu A.B., Lubala R.T., Eds.) Magmatism in extensional structural settings. Springer. Berlin, 1991, pp. 495-536.

Gurnis M., Hall C., Lavier L. Evolving force balance during incipient subduction. Geochem. Geophys. Geosyst., Vol. 5, No. 7, Q07001, 2004, pp. 1-31.

Gutenberg B., Benioff H., Burger J. M., Griggs D. Colloquium on plastic flow and deformation within the Earth. Eos Trans. of the American Geophysical Union, Vol. 32, No. 4, 1951, pp. 497-543.

Gutzmer J., Banks D., de Kock M.O., McClung C.R., Strauss $\mathrm{H}$., Mezger K. The origin and paleoenvironmental significance of stratabound barites from the mesoarchean fig tree group, Barberton mountainland, South Africa. Trans. of the V South American Symp. on Isotope Geology, contrib. Vol. 311, 2006, pp. 258-262.

Hacking I. Representing and intervening. Introductory topics in the philosophy of natural science. Cambridge Univ. Press. Cambridge, 1983, $286 \mathrm{p}$.

Hall J. Natural History of New York: Paleontology, Vol. 3, pt. 1, 1859, pp. 66-96.

Hamilton W.B. Archean magmatism and deformation were not products of plate tectonics. Precambrian Research, Vol. 91, 1998, pp. 143-179.

Hamilton W.B. The closed upper-mantle circulation of plate tectonics. In: (Stein S., Freymueller J.T., Eds.) Plate Boundary Zones, Geodynamics Series, Vol. 30, 2002, pp. 359-410.

Hamilton W.B. Driving mechanism and 3-D circulation of plate tectonics. Geol. Soc. America Special Paper Vol. 433, 2007a, pp. 1-25.

Hamilton W.B. Earth's first two billion years - The era of internally mobile crust. In: (Hatcher R.D., Jr., Carlson M.P., McBride J.H., Martínez Catalán J.R., Eds.) 4-D Framework of Continental Crust, Geol. Society of America Memoir, Vol. 200, 2007b, pp. 233-296.

Hamilton W. B. Plate tectonics began in Neoproterozoic time, and plumes from deep mantle have never operated. Lithos, Vol. 123, No. 1-4, 2011, pp. 1-20.

Harrison T. M., Blichert-Toft J., Müller W., Albarede F., Holden P., Mojzsis S.J. Heterogeneous Hadean hafnium: evidence
Grotzinger J.P., Kasting J.F. New constraints on Precambrian ocean composition. The Journal of Geology, Vol. 101, 1993, pp. 235-243.

Grove T.L., Parman S. Thermal evolution of the Earth as recorded by komatiites. Earth Planet. Sci. Lett., Vol. 219, 2004, pp. 173-187.

Gurney J.J., Moore R.O., Otter M.L., Kirkley M.B., Hops J.J., McCandless T.E. Southern African kimberlites and their xenoliths. In: (Kampunzu A.B. and Lubala R.T., Eds.) Magmatism in extensional structural settings. Springer. Berlin, 1991, pp. 495-536.

Gurnis M., Hall C., Lavier L. Evolving force balance during incipient subduction. Geochem. Geophys. Geosyst., Vol. 5, No. 7, Q07001, 2004, pp. 1-31.

Gutenberg B., Benioff H., Burger J. M., Griggs D. Colloquium on plastic flow and deformation within the Earth. Eos Trans. of the American Geophysical Union, Vol. 32, No. 4, 1951, pp. 497-543.

Gutzmer J., Banks D., de Kock M.O., McClung C.R., Strauss H., Mezger K. The origin and paleoenvironmental significance of stratabound barites from the mesoarchean fig tree group, Barberton mountainland, South Africa. Trans. of the V South American Symp. on Isotope Geology, contrib. Vol. 311, 2006, pp. 258-262.

Hacking I. Representing and intervening. Introductory topics in the philosophy of natural science. Cambridge Univ. Press. Cambridge, 1983, $286 \mathrm{p}$.

Hall J. Natural History of New York: Paleontology, Vol. 3, pt. 1, 1859, pp. 66-96.

Hamilton W.B. Archean magmatism and deformation were not products of plate tectonics. Precambrian Research, Vol. 91, 1998, pp. 143-179.

Hamilton W.B. The closed upper-mantle circulation of plate tectonics. In: (Stein S. and Freymueller J.T., Eds.), Plate Boundary Zones, Geodynamics Series, Vol. 30, 2002, pp. 359-410.

Hamilton W.B. Driving mechanism and 3-D circulation of plate tectonics. Geol. Soc. America Special Paper Vol. 433, 2007a, pp. 1-25.

Hamilton W.B. Earth's first two billion years - The era of internally mobile crust. In: (Hatcher R.D., Jr., Carlson M.P., McBride J.H., Martínez Catalán J.R., Eds.), 4-D Framework of Continental Crust, Geol. Society of America Memoir, Vol. 200, 2007b, pp. 233-296.

Hamilton W. B. Plate tectonics began in Neoproterozoic time, and plumes from deep mantle have never operated. Lithos, Vol. 123, No. 1-4, 2011, pp. 1-20.

Harrison T. M., Blichert-Toft J., Müller W., Albarede F., Holden P., Mojzsis S.J. Heterogeneous Hadean hafnium: evidence of continental crust at 4.4 to $4.5 \mathrm{Ga}$. Science, Vol. 310, No. 5756, 2005, pp. 1947-1950.

Harrison T.M., Blichert-Toft J., Müller W., Albarede F., Holden P., Mojzsis S.J. Response to Comment on "Heterogeneous hadean hafnium: evidence of continental crust at 4.4 to 4.5 Ga”. Science, 312, No. 5777, 2006, pp. 1139.

Harrison T.M., Watson E.B. Crystallization temperatures of hadean zircons: possible plate boundary interactions between 4.4 and $4.0 \mathrm{Ga}$. Proceed. of the Geol. Soc. of America Ann. Meet., Salt Lake City, Vol. 37, No. 7, 2005, p. 309.

Hasegawa A., Takagi A. Comparison of Wadati-Benioff zone geometry and distribution of earthquake generating stress beneath northeastern Japan and those beneath western South America. Tohoku Geophys. Jour., Vol. 31, 1987, pp. 1-18.

Herndon J.M. Inseparability of science history and discovery. Hist. Geo. Space Sci., Vol. 1, 2010, pp. 25-41.

Hess H.H. History of ocean basins. In: Petrologic studies: a volume to honor A.F.Buddington. Boulder, CO, Geol. Society of America. 1962, pp. 599-620.

Hey R.N. Seafloor spreading. In: (Gupta H., Ed.) Encyclopedia of solid earth geophysics, Springer. Dordrecht, 2011, pp. 1055-1059. 
of continental crust at 4.4 to $4.5 \mathrm{Ga}$. Science, Vol. 310 , No. 5756, 2005, pp. 1947-1950.

Harrison T.M., Blichert-Toft J., Müller W., Albarede F., Holden P., Mojzsis S.J. Response to Comment on "Heterogeneous hadean hafnium: evidence of continental crust at 4.4 to 4.5 Ga”. Science, 312, No. 5777, 2006, pp. 1139.

Harrison T.M., Watson E.B. Crystallization temperatures of hadean zircons: possible plate boundary interactions between 4.4 and 4.0 Ga. Proceed. of the Geol. Soc. of America Ann. Meet., Salt Lake City, Vol. 37, No. 7, 2005, p. 309.

Hasegawa A., Takagi A. Comparison of Wadati-Benioff zone geometry and distribution of earthquake generating stress beneath northeastern Japan and those beneath western South America. Tohoku Geophys. Journ., Vol. 31, 1987, pp. 1-18.

Herndon J.M. Inseparability of science history and discovery. Hist. Geo. Space Sci., Vol. 1, 2010, pp. 25-41.

Hess H.H. History of ocean basins. In: Petrologic studies: a volume to honor A.F.Buddington. Boulder, CO, Geol. Society of America. 1962, pp. 599-620.

Hey R.N. Seafloor spreading. In: (Gupta H., Ed.) Encyclopedia of solid earth geophysics, Springer. Dordrecht, 2011, pp. 1055-1059.

Holmes A. Radioactivity and continental drift. Geological Magazine, Vol. 65, 1928a, pp. 236-238.

Holmes A. Continental drift. Nature, Vol. 122, 1928b, pp. 431-433.

Holmes A. A review of the continental drift hypothesis. The Mining Magazine, Vol. 40, 1929, pp. 205-209, pp.286-288, pp. 340-347.

Holmes A. Radioactivity and geology. Verh. Nat. Ges. Basel, Vol. 41, 1930, pp. 136-185 (in German).

Holmes A. Radioactivity and earth movements. Trans. of the Geological Society of Glasgow for 1928-29, Vol. 18, 1931, pp. 559-606.

Holmes A. Principles of physical geology. Thomas Nelson. London, UK, 1944, 532 p.

Hopkins W. Researches in physical geology. Philos. Trans. R. Soc. London, Vol. 129, 1839, pp. 381-385.

Hopkins W. Report on the geological theories of elevation and earthquakes. Report to the British Association for 1847, 1847, pp. 33-92.

Isacks B., Oliver J., Sykes L.R. Seismology and the new global tectonics. Journ. of Geophysical Research, Vol. 73, No. 18, 1968, pp. 5855-5899.

Ivin A.A. Art of thinking correctly. Prosveschenie. Moscow, 1986, 224 p. (in Russian).

Jacobs J.A., Russell R.D., Wilson J.T. Physics and geology. $2^{\text {nd }}$ ed. McGraw-Hill. NY, 1973, 622 p.

Jacoby W.R. Plate sliding and sinking in mantle convection and the driving mechaism. In: (Davis P.A., Runcorn F.R.S., Eds.) Mechanisms of continental drift and plate tectonics. Academic Press. NY, 1980, pp. 159-172.

Jeffreys H. On the Earth's thermal history and some related geological phenomena. Gerlands Beiträge zur Geophysik, Vol. 18, 1927, pp.1-29.

Joly J. Radioactivity and Geology. Archibald Constable and Co. London, UK, 1909, 287 p.

Jordan T.H., Lerner-Lam A.L., Creager K.C. Seismic imaging of boundary layers and deep mantle convection. In: (Peltier W.R., Ed.) Mantle convection: plate tectonics and global dynamics. The fluid mechanics of astrophysics and geophysics. Vol. 4, Gordon and Breach Science Publishers. 1989, pp. 97-201.

Jurdy D., Stefanick M. The forces driving the plates: Constraints from kinematics and stress observations. Philos. Trans. R. Soc., London, Ser. A, Vol. 337, 1991, pp. 127-138.

Kearey Ph., Klepei S.K., Vine F.J. Global tectonics. $3^{\text {rd }}$ ed. Willey-Blackwell. Singapore, 2009, 496 p.

Keppie D.F. How the closure of paleo-Tethys and Tethys oceans controlled the early breakup of Pangaea. Geology, Vol. 43, No. 4, 2015, pp. 335-338.
Holmes A. Radioactivity and continental drift. Geological Magazine, Vol. 65, 1928a, pp. 236-238.

Holmes A. Continental drift. Nature, Vol. 122, 1928b, pp. 431-433.

Holmes A. A review of the continental drift hypothesis. The Mining Magazine, Vol. 40, 1929, pp. 205-209, pp. 286-288, pp. 340-347.

Holmes A. Radioactivity and earth movements. Trans. of the Geological Society of Glasgow for 1928-29, Vol. 18, 1931, pp. 559-606.

Holmes A. Principles of physical geology. Thomas Nelson. London, UK, 1944, $532 \mathrm{p}$

Hopkins W. Researches in physical geology. Philos. Trans. R. Soc. London, Vol. 129, 1839, pp. 381-385.

Hopkins W. Report on the geological theories of elevation and earthquakes. Report to the British Association for 1847. 1847, pp. 33-92.

Isacks B., Oliver J., Sykes L.R. Seismology and the new global tectonics. Jour. of Geophysical Research, Vol. 73, No. 18, 1968, pp. 5855-5899.

Jacobs J.A., Russell R.D., Wilson J.T. Physics and geology. $2^{\text {nd }}$ ed. McGraw-Hill. NY, 1973, 622 p.

Jacoby W.R. Plate sliding and sinking in mantle convection and the driving mechaism. In: (Davis P.A., Runcorn F.R.S., Eds.). Mechanisms of continental drift and plate tectonics, Academic Press. NY, 1980, pp. 159-172.

Jeffreys H. On the Earth's thermal history and some related geological phenomena. Gerlands Beiträge zur Geophysik, Vol. 18, 1927, pp. 1-29.

Joly J. Radioactivity and Geology. Archibald Constable and Co. London, UK, 1909, 287 p.

Jordan T.H., Lerner-Lam A.L., Creager K.C. Seismic imaging of boundary layers and deep mantle convection. In: (Peltier W.R., Ed.) Mantle convection: plate tectonics and global dynamics. The fluid mechanics of astrophysics and geophysics. Vol. 4, Gordon and Breach Science Publishers. 1989, pp. 97-201.

Jurdy D., Stefanick M. The forces driving the plates: Constraints from kinematics and stress observations. Philos. Trans. R. Soc., London, Ser. A, Vol. 337, 1991, pp. 127-138.

Kearey Ph., Klepei S.K., Vine F.J. Global tectonics. $3^{\text {rd }}$ ed. Willey-Blackwell. Singapore, 2009, 496 p.

Keppie D.F. How the closure of paleo-Tethys and Tethys oceans controlled the early breakup of Pangaea. Geology, Vol. 43, No. 4, 2015, pp. 335-338.

Kerr R.A. Earth's surface may move itself. Science, Vol. 269, 1995, pp. 214-1216.

Kirdyashkin A.A., Kirdyashkin A.G. Forces acting on a subducting oceanic plate. Geotectonics, Vol. 48, No. 1, 2014, pp. 54-67.

Klein C. Some Precambrian banded iron formations (BIFs) from around the world: Their age, geologic setting, mineralogy, metamorphism, geochemistry and origin. American Mineralogist, Vol. 90, No. 10, 2005, pp. 1473-1499.

Knauth L.P., Lowe D.R. High Archean climatic temperature inferred from oxygen isotope geochemistry of cherts in the 3.5 Ga Swaziland Supergroup, South Africa. Bull. of the Geol. Soc. of Amer., Vol. 115, No. 5, 2003, pp. 566-580.

Knight J.T., Ridley J.R., Groves D.I. The Archean amphibolite facies Coolgardie Goldfield, Yilgarn Craton, Western Australia: nature, controls, and gold field-scale patterns of hydrothermal wall-rock alteration. Economic Geology, Vol. 95, No. 1, 2000, pp. 49-84.

Knopf A. Analysis of some recent geosynclinal theory. American Journ. of Science, Bradley Vol. 258-A, 1960, pp. 126-136.

Knopoff L. The convection current hypothesis. Reviews of Geophysics, Vol. 2, 1964, pp. 89-123.

Korenaga J. Plate tectonics, flood basalts and the evolution of Earth's oceans. Terra Nova, Vol. 20, No. 6, 2008, pp. 419-439. 
Kerr R.A. Earth's surface may move itself. Science, Vol. 269, 1995, pp. 214-1216.

Khain V.Ye. The General geotectonics. Nedra. Moscow, 1973, 512 p. (in Russian).

Khain V.Ye. Tectonics of continents and oceans. Nauchnyi Mir. Moscow, 2001, 606 p. (in Russian).

Khain V.E., Koronovsky N.V. Planet Earth from core to ionosphere. KDU, Moscow, 2007, 244 p. (in Russian).

Khain V.Ye., Sheinmann Yu.M. A hundred years of studying geosynclines. Sovetskaya geologiya, No. 11, 1960, pp. 3-44 (in Russian).

Kirdyashkin A.A., Kirdyashkin A.G. Forces acting on a subducting oceanic plate. Geotectonics, Vol. 48, No. 1, 2014, pp. 54-67.

Klein C. Some Precambrian banded iron formations (BIFs) from around the world: Their age, geologic setting, mineralogy, metamorphism, geochemistry and origin. American Mineralogist, Vol. 90, No. 10, 2005, pp. 1473-1499.

Knauth L.P., Lowe D.R. High Archean climatic temperature inferred from oxygen isotope geochemistry of cherts in the 3.5 Ga Swaziland Supergroup, South Africa. Bull. of the Geol. Soc. of Amer., Vol. 115, No. 5, 2003, pp. 566-580.

Knight J.T., Ridley J.R., Groves D.I. The Archean amphibolite facies Coolgardie Goldfield, Yilgarn Craton, Western Australia: nature, controls, and gold field-scale patterns of hydrothermal wall-rock alteration. Economic Geology, Vol. 95, No. 1, 2000, pp. 49-84.

Knopf A. Analysis of some recent geosynclinal theory. American Journ. of Science, Bradley Vol. 258-A, 1960, pp. 126-136.

Knopoff L. The convection current hypothesis. Reviews of Geophysics, Vol. 2, 1964, pp. 89-123.

Kober L. The construction of the Earth. Gebrüder Borntraeger. Berlin, 1921, 324 p. (in German).

Korenaga J. Plate tectonics, flood basalts and the evolution of Earth's oceans. Terra Nova, Vol. 20, No. 6, 2008, pp. 419-439.

Kröner A., Layer P.W. Crust formation and plate motion in the Early Archean. Science, Vol. 256, No. 5, 1992, pp. 1405-1411.

Lambert I.B. Early geobiochemical evolution of the Earth. Revista Brasileira de Geociências, Vol. 12, 1982, pp. 32-38.

Lee $\mathrm{Ch}$. Effects of radiogenic heat production and mantle compressibility on the behaviors of Venus' and Earth's mantle and lithosphere. Geosciences Journ., Vol. 18, No. 1, 2014 pp. 13-30.

Le Pichon X. Sea-floor spreading and continental drift. Journ. of Geophysical Research, Vol. 73, No. 12, 1968, pp. 3661-3696.

Leviton A., Aldrich M., Laudan R. Frank Bursley Taylor's theory of continental drift. Earth Sciences History, Vol. 4 No. 2, 1985, pp. 118-121.

Lithgow-Bertelloni C., Richards M.A. Cenozoic plate driving forces. Geophys. Research Lett., Vol. 22, No. 11, 1995, pp. 1317-1320.

Liu L. The inception of the oceans and CO2-atmosphere in the early history of the Earth. Earth and Planet. Sci. Lett., Vol. 227, No. 3-4, 2004, pp. 179-184.

Lowe D.R. Early environments: Constraints and opportunities for early evolution. In: Early life on Earth. Nobel Symposium, No.84 (Bengston S., Ed.), Columbia Univ. Press. N.Y., 1994, pp. 10-23.

Lyttleton R.A., Bondi H. How plate tectonics may appear to a physicist. Journ. of the British Astronomical Assoc., Vol. 102, No. 4, 1992, pp. 194-195.

Lyubetskaya T., Korenaga J. Chemical composition of Earth's primitive mantle and its variance: 2 . Implications for global geodynamics. Journ. of Geophysical Research, Vol. 112, No. B03211, 2007, DOI: 10.1029/2005JB004223.

Mahatsente R., Ranalli G. Time evolution of negative buoyancy of an oceanic slab subducting with varying velocity. Journ. of Geodynamics, Vol. 38, No. 2, 2004, pp. 117-129.
Kröner A., Layer P.W. Crust formation and plate motion in the Early Archean. Science, Vol. 256, No. 5, 1992, pp. 1405-1411.

Lambert I.B. Early geobiochemical evolution of the Earth. Revista Brasileira de Geociências, Vol. 12, 1982, pp. 32-38.

Lee Ch. Effects of radiogenic heat production and mantle compressibility on the behaviors of Venus' and Earth's mantle and lithosphere. Geosciences Journ., Vol. 18, No. 1, 2014, pp. 13-30.

Le Pichon X. Sea-floor spreading and continental drift. Journ. of Geophysical Research, Vol. 73, No. 12, 1968, pp. 3661-3696.

Leviton A., Aldrich M., Laudan R. Frank Bursley Taylor's theory of continental drift. Earth Sciences History, Vol. 4, No. 2, 1985, pp. 118-121.

Lithgow-Bertelloni C., Richards M.A. Cenozoic plate driving forces. Geophys. Research Lett., Vol. 22, No. 11, 1995, pp. 1317-1320.

Liu L. The inception of the oceans and CO2-atmosphere in the early history of the Earth. Earth and Planet. Sci. Lett., Vol. 227, No. 3-4, 2004, pp. 179-184.

Lowe D.R. Early environments: Constraints and opportunities for early evolution. In: Early life on Earth. Nobel Symposium, No.84 (Bengston S., Ed.), Columbia Univ. Press, N.Y., 1994, pp. 10-23.

Lyttleton R.A., Bondi H. How plate tectonics may appear to a physicist. Journ. of the British Astronomical Assoc., Vol. 102, No. 4, 1992, pp. 194-195.

Lyubetskaya T., Korenaga J. Chemical composition of Earth's primitive mantle and its variance: 2 . Implications for global geodynamics. Journ. of Geophysical Research, Vol. 112, No. B03211, 2007, DOI: 10.1029/2005JB004223.

Mahatsente R., Ranalli G. Time evolution of negative buoyancy of an oceanic slab subducting with varying velocity. Journ. of Geodynamics, Vol. 38, No. 2, 2004, pp. 117-129.

Mallet J.L. Numerical earth models. Europ. Assoc. of Geoscientists and Engin. EAGE Publications. 2008, 148 p.

Mariano G., Sial A.N., Herz N. Oxygen isotope geochemistry of a potássio porphyritic calc-alkalic composite pluton: the itaporanga batholith, state of Paraíba, northeastern Brazil. Revista Brasileira de Geociências, Vol. 20, No. 1-4, 1990, pp.159-164.

Maruyama S., Santosh M., Azuma S. Initiation of plate tectonics in the Hadean: Eclogitization triggered by the ABEL Bombardment. Geoscience Frontiers, Vol. 9, 2018, pp.1033-1048.

McKenzie D.P. Speculations on the consequences and causes of plate motions. Geophysical Journ. of the Royal Astron. Soc., Vol. 18, No. 1, 1969, pp. 1-32.

McKenzie D.P. Plate tectonics and its relationship to the evolution of ideas in the geologic sciences. Daedalus, Vol. 106, No. 3, 1977, pp. 97-124.

McKenzie D., Parker, R.L. The North Pacific: an example of tectonics on a sphere. Nature, Vol. 216, 1967, pp. 1276-1280.

Meijer P.T., Wortel M.J.R. Dynamics of the South American plate. Journ. of Geophys. Research, Vol. 97, 1992, pp. 11915-11931.

Meissner R. The little book of planet Earth. Copernicus Books. NY, USA, 2002, 204 p.

Meyerhoff A.A., Meyerhoff H.A. Plate tectonics, evidence against. Structural geology and tectonics. In: Encyclopedia of Earth Science, 1987, pp. 549-560.

Mojzsis S.J., Coath C.D., Greenwood J.P., McKeegan K.D., Harrison T.M. Mass-independent isotope effects in Archean (2.5 to $3.8 \mathrm{Ga}$ ) sedimentary sulfides determined by ion microprobe analysis. Geochim. et Cosmoch. Acta, Vol. 67, No. 9, 2003, pp. 1635-1658.

Morgan W.J. Rises, trenches, great faults, and crustal blocks. Journ. of Geophys. Research, Vol. 73, No. 6, 1968, pp. 1959-1982. 
Mallet J.L. Numerical earth models. Europ. Assoc. of Geoscientists and Engin. EAGE Publications. 2008, 148 p.

Mariano G., Sial A.N., Herz N. Oxygen isotope geochemistry of a potássio porphyritic calc-alkalic composite pluton: the itaporanga batholith, state of Paraíba, northeastern Brazil. Revista Brasileira de Geociências, Vol. 20, No. 1-4, 1990, pp. 159-164.

Maruyama S., Santosh M., Azuma S. Initiation of plate tectonics in the Hadean: Eclogitization triggered by the ABEL Bombardment. Geoscience Frontiers, Vol. 9, 2018, pp. 1033-1048.

McKenzie D.P. Speculations on the consequences and causes of plate motions. Geophysical Journ. of the Royal Astron. Soc., Vol. 18, No. 1, 1969, pp.1-32.

McKenzie D.P. Plate tectonics and its relationship to the evolution of ideas in the geologic sciences. Daedalus, Vol. 106, No. 3, 1977, pp. 97-124.

McKenzie D., Parker, R.L. The North Pacific: an example of tectonics on a sphere. Nature, Vol. 216, 1967, pp. 1276-1280.

Meijer P.T., Wortel M.J.R. Dynamics of the South American plate. Journ. of Geophys. Research, Vol. 97, 1992, pp. 11915-11931.

Meissner R. The little book of planet Earth. Copernicus Books. NY, USA, 2002, 204 p.

Meyerhoff A.A., Meyerhoff H.A. Plate tectonics, evidence against. Structural geology and tectonics. In: Encyclopedia of Earth Science, 1987, pp. 549-560.

Mojzsis S.J., Coath C.D., Greenwood J.P., McKeegan K.D., Harrison T.M. Mass-independent isotope effects in Archean $(2.5$ to $3.8 \mathrm{Ga})$ sedimentary sulfides determined by ion microprobe analysis. Geochim. et Cosmoch. Acta, Vol. 67, No. 9, 2003, pp. 1635-1658.

Morgan W.J. Rises, trenches, great faults, and crustal blocks. Journ. of Geophys. Research, Vol. 73, No. 6, 1968, pp. 1959-1982.

Morse J.W., Mackenzie F.T. Hadean Ocean carbonate geochemistry. Aquatic Geochemistry, Vol. 4, No. 3-4, 1998, pp. 301-319.

Müller R.D., Sdrolias M., Gaina C., Roest W.R. Age, spreading rates, and spreading asymmetry of the world's ocean crust. Geochemistry, Geophysics, Geosystems, Vol. 9, No. 4, 2008, pp. 1-19.

Naimark A.A. A half a century of fixists and mobilist discussions: analysis of reality or hypotheses, search for truth or "convenient" theory? Bull. of Kamchatka Regional Ass. "TeachingScience Center", Vol. 2, No. 8, 2006, 177-186 (in Russian).

Nance R.D., Murphy B. Origins of the supercontinent cycle. Geoscience Frontiers, Vol. 4, No. 4, 2013, pp. 439-448.

Nebel O., Rapp R.P., Yaxley G.M. The role of detrital zircons in Hadean crustal research. Lithos, 2014, pp. 190-191; 313-327.

Nisbet E.G., Sleep N.H. The habitat and nature of early life. Nature, Vol. 409, 2001, pp. 1083-1091.

Nunn J.F. Evolution of the atmosphere. Proceed. of Geol Assoc., Vol. 109, No. 1, 1998, pp. 1-13.

Nutman A.P., Friend C.R.L., Bennett V.C. Evidence for 3650$3600 \mathrm{Ma}$ assembly of the northern end of the Itsaq Gneiss Complex, Greenland: implication for early Archean tectonics. Tectonics, Vol. 21, 2002, pp. 1-28.

Nutman A.P., Mojzsis S.J., Friend C.R. Recognition of $\geq 3850$ Ma water-lain sediments in West Greenland and their significance for the early Archaean Earth. Geochim. et Cosmochim. Acta, Vol. 61, No. 12, 1997, pp. 2475-2484.

O'Neil J., Carlson R.W. The Nuvvuagittuq Greenstone Belt: A case of Hadean subduction? GSA Annual Meeting in Vancouver, British Columbia (19-22 October 2014). Geol. Soc. of America Abstracts with Programs, Vol. 46, No. 6, 2014, p. 282.

Ortelius A. Thesaurus Geographicus Leaf Nnn verso. $3^{\text {rd }}$ ed. Plantin. Antwerp, Belgium, 1596.
Morse J.W., Mackenzie F.T. Hadean Ocean carbonate geochemistry. Aquatic Geochemistry, Vol. 4, No. 3-4, 1998, pp. 301-319.

Müller R.D., Sdrolias M., Gaina C., Roest W.R. Age, spreading rates, and spreading asymmetry of the world's ocean crust. Geochemistry, Geophysics, Geosystems, Vol. 9, No. 4, 2008, pp.1-19.

Nance R.D., Murphy B. Origins of the supercontinent cycle. Geoscience Frontiers, Vol. 4, No. 4, 2013, pp. 439-448.

Nebel O., Rapp R.P., Yaxley G.M. The role of detrital zircons in Hadean crustal research. Lithos, 2014, pp. 190-191; 313-327.

Nisbet E.G., Sleep N.H. The habitat and nature of early life. Nature, Vol. 409, 2001, pp. 1083-1091.

Nunn J.F. Evolution of the atmosphere. Proceed. of Geol Assoc., Vol. 109, No. 1, 1998, pp. 1-13.

Nutman A.P., Friend C.R.L., Bennett V.C. Evidence for 3650$3600 \mathrm{Ma}$ assembly of the northern end of the Itsaq Gneiss Complex, Greenland: implication for early Archean tectonics. Tectonics, Vol. 21, 2002, pp. 1-28.

Nutman A.P., Mojzsis S.J., Friend C.R. Recognition of $\geq 3850$ Ma water-lain sediments in West Greenland and their significance for the early Archaean Earth. Geochim. et Cosmochim. Acta, Vol. 61, No. 12, 1997, pp. 2475-2484.

O'Neil J., Carlson R.W. The Nuvvuagittuq Greenstone Belt: A case of Hadean subduction? GSA Annual Meeting in Vancouver, British Columbia (19-22 October 2014). Geol. Soc. of America Abstracts with Programs, Vol. 46, No. 6, 2014, p.282.

Ortelius A. Thesaurus Geographicus Leaf Nnn verso. $3^{\text {rd }}$ ed. Plantin. Antwerp, Belgium, 1596.

Pastor-Galán D., Nance R.D., Murphy J.B., Spencer C.J. Supercontinents: myths, mysteries, and milestones. Geological Society of London, Special Publication, Vol. 470, 2018, 1-27.

Pearson D.G., Canil D., Shirey S.B. Mantle samples included in volcanic rocks: xenoliths and diamonds. In: (Carlson R.W., Ed.) Treatise on geochemistry, Vol. 2, The Mantle. Elsevier. N.Y., 2003, pp. 171-277.

Pechersky D.M., Eppelbaum L.V. Peering into the past: what happened to the Moon 3.6 billion years ago? Positioning, Vol. 9, No. 3, 2018, pp. 73-78.

Peck W.H., Valley J.W., Wilde S.A., Graham C.M. Oxygen isotope ratios and rare earth elements in 3.3 to $4.4 \mathrm{Ga}$ zircons: Ion microprobe evidence for high $\mathrm{H}^{18} \mathrm{O}$ continental crust and oceans in the Early Archean. Geochim. et Cosmochim. Acta, Vol. 65, No. 22, 2001, pp. 4215-4229.

Petrini K., Podladchikov Yu. Lithospheric pressure-depth relationship in compressive regions of thickened crust. Jour. of Metamorphic Geol., Vol. 18, 2000, pp. 67-78.

Pilchin A.N. The role of serpentinization in exhumation of highto ultra-high-pressure metamorphic rocks. Earth and Plan. Sci. Lett., Vol. 237, No. 3-4, 2005, pp. 815-828.

Pilchin A.N. Magnetite: The story of the mineral's formation and stability. In: (Angrove D.M., Ed.) Magnetite: structure, properties and applications. Nova Science Publ., NY, Chapter 1, 2011, pp. 1-99.

Pilchin A. Comparing the tectonic conditions on Venus with tectonic conditions of Early Archean Earth. Trans. of the workshop on comparative tectonics and geodynamics of Venus, Earth, and Rocky Exoplanets. Pasadena, California, USA, Abst. 2015, p. 5003.

Pilchin A. Comparison of thermodynamic conditions of early Venusian atmosphere with those of the early Earth and Mars atmospheres. Trans. of the $47^{\text {th }}$ Lunar and Planetary Sci. Conf., Abstract, 2016a, p. 1042.

Pilchin A. Critical analysis of the plate tectonics model and causes of horizontal tectonic movements. New Concepts in Global Tectonics Journal, Vol. 4, No. 2, 2016b, pp. 204-272.

Pilchin A.N., Eppelbaum L.V. Some peculiarities of thermodynamic conditions in the Earth's crust and upper mantle. Scientific Israel, No. 1-2, 2002, pp. 117-142. 


\section{Geology and geophysics}

Pastor-Galán D., Nance R.D., Murphy J.B., Spencer C.J. Supercontinents: myths, mysteries, and milestones. Geological Society of London, Special Publication, Vol. 470, 2018, 1-27.

Pearson D.G., Canil D., Shirey S.B. Mantle samples included in volcanic rocks: xenoliths and diamonds. In: (Carlson R.W., Ed.) Treatise on geochemistry, Vol. 2, The Mantle. Elsevier. N.Y., 2003, pp. 171-277.

Pechersky D.M., Eppelbaum L.V. Peering into the past: what happened to the Moon 3.6 billion years ago? Positioning, Vol. 9, No. 3, 2018, pp. 73-78.

Peck W.H., Valley J.W., Wilde S.A., Graham C.M. Oxygen isotope ratios and rare earth elements in 3.3 to $4.4 \mathrm{Ga}$ zircons: Ion microprobe evidence for high $\mathrm{H}^{18} \mathrm{O}$ continental crust and oceans in the Early Archean. Geochim. et Cosmochim. Acta, Vol. 65, No. 22, 2001, pp. 4215-4229.

Petrini K., Podladchikov Yu. Lithospheric pressure-depth relationship in compressive regions of thickened crust. Journ. of Metamorphic Geol., Vol. 18, 2000, pp. 67-78.

Pilchin A.N. The role of serpentinization in exhumation of highto ultra-high-pressure metamorphic rocks. Earth and Plan. Sci. Lett., Vol. 237, No. 3-4, 2005, pp. 815-828.

Pilchin A.N. Magnetite: The story of the mineral's formation and stability. In: (Angrove D.M., Ed.) Magnetite: structure, properties and applications. Nova Science Publ., NY, Chapter 1, 2011, pp. 1-99.

Pilchin A. Comparing the tectonic conditions on Venus with tectonic conditions of Early Archean Earth. Trans. of the workshop on comparative tectonics and geodynamics of Venus, Earth and Rocky Exoplanets. Pasadena, California, USA, Abst. 2015, p. 5003.

Pilchin A. Comparison of thermodynamic conditions of early Venusian atmosphere with those of the early Earth and Mars atmospheres. Trans. of the $47^{\text {th }}$ Lunar and Planetary Sci. Conf., Abstract, 2016a, p. 1042.

Pilchin A. Critical analysis of the plate tectonics model and causes of horizontal tectonic movements. New Concepts in Global Tectonics Journal, Vol. 4, No. 2, 2016b, pp. 204-272.

Pilchin A.N., Eppelbaum L.V. Some peculiarities of thermodynamic conditions in the Earth's crust and upper mantle. Scientific Israel, No. 1-2, 2002, pp. 117-142.

Pilchin A.N., Eppelbaum L.V. Some causes of initial mantle heterogeneity. Trans. of the 33rd Intern. Geological Conf., Oslo, Norway, EID05422P, 2008.

Pilchin A.N., Eppelbaum L.V. The early Earth and formation of the lithosphere. In: (Anderson J.E., Coates R.W., Eds.) the lithosphere: geochemistry, geology and geophysics. Nova Science Publ., NY, USA, Chapter 1, 2009, pp. 1-68.

Pilchin A., Eppelbaum L. The early Earth formation and evolution of the lithosphere in the Hadean - Middle Archean. In: (Sato F., Nakamura Sh., Eds.) Encyclopedia of Earth Science Research, Vol. 1, Chapter 1, 2012, pp. 1-93.

Pratt D. Plate tectonics: A paradigm under threat. Journ. of Scientific Exploration, Vol. 14, No. 3, 2000, pp. 307-352.

Rapp R.P., Yaxley G.M., Norman M.D. Continent formation in the Archean and chemical evolution of the cratonic lithosphere. Trans. of the $9^{\text {th }}$ Intern. Kimberlite Conf., Extended Abstract, No. 9IKC-A-00341, 2008.

Rayleigh Lord. On convection currents in a horizontal layer of fluid, when the higher temperature is on the underside. The London, Edinburgh and Dublin Phil. Magazine and Jour. of Science, Vol. 32, No. 192, 1916, pp. 529-546.

Richards I.J., Gregory R.T., Ferguson K.M., Douthitt C.B. Archean hydrothermal alteration and metamorphism of the Pilbara block, Western Australia. Proceed. of the GSA Ann. Meet., Paper No. 165-0, 2001.

Richardson R.M. Inversion for the driving forces of plate tectonics. Proc. IEEE Intl. Geosci. and Remote Sensing Symp., II, 1983, p. FA2.3.1-FA2.3.6.
Pilchin A.N., Eppelbaum L.V. Some causes of initial mantle heterogeneity. Trans. of the 33rd Intern. Geological Conf., Oslo, Norway, EID05422P, 2008.

Pilchin A.N., Eppelbaum L.V. The early Earth and formation of the lithosphere. In: (Anderson J.E., Coates R.W., Eds.) the lithosphere: geochemistry, geology and geophysics. Nova Science Publ., NY, USA, Chapter 1, 2009, pp. 1-68.

Pilchin A., Eppelbaum L. The early Earth formation and evolution of the lithosphere in the Hadean - Middle Archean. In: (Sato F., Nakamura Sh., Eds.), Encyclopedia of Earth Science Research, Vol. 1, Chapter 1, 2012, pp. 1-93.

Pratt D. Plate tectonics: A paradigm under threat. Journ. of Scientific Exploration, Vol. 14, No. 3, 2000, pp. 307-352.

Rapp R.P., Yaxley G.M., Norman M.D. Continent formation in the Archean and chemical evolution of the cratonic lithosphere. Trans. of the $9^{\text {th }}$ Intern. Kimberlite Conf., Extended Abstract, No. 9IKC-A-00341, 2008.

Rayleigh Lord. On convection currents in a horizontal layer of fluid, when the higher temperature is on the underside. The London, Edinburgh and Dublin Phil. Magazine and Jour. of Science, Vol. 32, No. 192, 1916, pp. 529-546.

Richards I.J., Gregory R.T., Ferguson K.M., Douthitt C.B. Archean hydrothermal alteration and metamorphism of the Pilbara block, Western Australia. Proceed. of the GSA Ann. Meet., Paper No. 165-0, 2001.

Richardson R.M. Inversion for the driving forces of plate tectonics. Proc. IEEE Intl. Geosci. and Remote Sensing Symp., II, 1983, p. FA2.3.1-FA2.3.6.

Richardson R.M. Ridge forces, absolute plate motions, and the intraplate stress field. Journ. of Geophysical Research, Vol. 97, 1992, pp. 11739-11748.

Richter F.M. Dynamical models for sea floor spreading. Rev. Geophys. Space Phys., No. 2, 1973, pp. 11 223-11 287.

Riguzzi F., Panza G., Vargan P., Doglioni C. Can Earth's rotation and tidal despinning drive plate tectonics? Tectonophysics, Vol. 484, 2010, pp. 60-73.

Roger K. Scientific modeling. Encyclopædia Britannica, Inc. 2015.

Romm J. A new forerunner for continental drift. Nature, Vol. 367, No. 6462, 1994, pp. 407-408.

Royden L.H., Husson L. Subduction with variations in slab buoyancy: Models and application to the Banda and Apennine systems. In: (Lallemand S., Funiciello C., Eds.) Subduction zone geodynamics - frontiers in Earth sciences. Springer-Verlag. Berlin - Heidelberg, 2009, pp.35-45.

Santosh M., Maruyama S., Yamamoto S. The making and breaking of supercontinents: some speculations based on superplumes, super downwelling and the role of tectosphere. Gondwana Research, Vol. 15, No. 3-4, 2009, pp. 324-341.

Schellart W.P. Quantifying the net slab pull force as a driving mechanism for plate tectonics. Geophysical Research Lett., Vol. 31, L07611, 2004, pp. 1-5.

Schubert G., Stevenson D., Cassen P. Whole planet cooling and the radiogenic heat source contents of the Earth and Moon. Jour. of Geophys. Research, Vol. 85, No. B5, 1980, 2531-2538.

Schubert G., Turcotte D. L., Olson P. Mantle convection in the Earth and planets. Cambridge Univ. Press, Cambridge, UK, 2001, 940 p.

Schulze D.J. Constraints on the abundance of eclogite in the upper mantle. Journ. of Geophysical Research, Vol. 94, No. B4, 1989, pp. 4205-4212.

Schwarz Ch. V., Reiser B.J., Davis E.A., Kenyon L., Achér A., Fortus D., Shwartz Y., Hug B., Krajcik J., Developing a learning progression for scientific modeling: making scientific modeling accessible and meaningful for learners. Journ. of Research in Science Teaching, Vol. 46, No. 6, 2009, pp. 632-654.

Skobelin E.A., Sharapov I.P., Bugayov A.F. Deliberations of state and ways of perestroika in geology (Has plate tectonics resulted in a revolution in geology?). In: Critical As- 
Richardson R.M. Ridge forces, absolute plate motions, and the intraplate stress field. Journ. of Geophysical Research, Vol. 97, 1992, pp. 11739-11748.

Richter F.M. Dynamical models for sea floor spreading. Rev. Geophys. Space Phys., No. 2, 1973, pp. 11 223-11 287.

Riguzzi F., Panza G., Vargan P., Doglioni C. Can Earth's rotation and tidal despinning drive plate tectonics? Tectonophysics, Vol. 484, 2010, pp. 60-73.

Roger K. Scientific modeling. Encyclopædia Britannica, Inc. 2015.

Romm J. A new forerunner for continental drift. Nature, Vol. 367, No. 6462, 1994, pp. 407-408.

Royden L.H., Husson L. Subduction with variations in slab buoyancy: Models and application to the Banda and Apennine systems. In: (Lallemand S., Funiciello C., Eds.) Subduction zone geodynamics - frontiers in Earth sciences. Springer-Verlag. Berlin - Heidelberg, 2009, pp. 35-45.

Santosh M., Maruyama S., Yamamoto S. The making and breaking of supercontinents: some speculations based on superplumes, super downwelling and the role of tectosphere. Gondwana Research, Vol. 15, No. 3-4, 2009, pp. 324-341.

Schellart W.P. Quantifying the net slab pull force as a driving mechanism for plate tectonics. Geophysical Research Lett., Vol. 31, L07611, 2004, pp. 1-5.

Schmeling H. Geodynamics. University of Frankfurt, 2004 (in German).

Schubert G., Stevenson D., Cassen P. Whole planet cooling and the radiogenic heat source contents of the Earth and Moon. Jour. of Geophys. Research, Vol. 85, No. B5, 1980, 2531-2538.

Schubert G., Turcotte D. L., Olson P. Mantle convection in the Earth and planets. Cambridge Univ. Press, Cambridge, UK, 2001, 940 p.

Schulze D.J. Constraints on the abundance of eclogite in the upper mantle. Journ. of Geophysical Research, Vol. 94, No. B4, 1989, pp. 4205-4212.

Schwarz Ch. V., Reiser B.J., Davis E.A., Kenyon L., Achér A., Fortus D., Shwartz Y., Hug B., Krajcik J., Developing a learning progression for scientific modeling: making scientific modeling accessible and meaningful for learners. Journ. of Research in Science Teaching, Vol. 46, No. 6, 2009, pp. 632-654.

Schwinner R. Analogies in the construction of the Eastern Alps. Centralblatt. New yearbook for mineralogy, geology and paleontology. Stuttgart, 1915, pp. 52-62 (in German).

Schwinner R. Volcanism and mountain building. One attempt. Journal of Volcanology, No. 5, 1919, pp. 175-230 (in German).

Skobelin E.A., Sharapov I.P., Bugayov A.F. Deliberations of state and ways of perestroika in geology (Has plate tectonics resulted in a revolution in geology?). In: Critical Aspects of the Plate Tectonics Theory, Vol. 1 - Athens (Greece): Theophrastus Publications, 1990, pp. 17-37.

Sharkov E.V., Bogatikov O.A. Early stages of the tectonic and magmatic development of the Earth and Moon: similarities and differences. Petrology, Vol. 9, No. 2, 2001, pp. 97-118.

Sharp Z.D., Papike J.J., Durakiewicz T. The effect of thermal decarbonation on stable isotope compositions of carbonates. Amer. Mineralogist, Vol. 88, No. 1, 2003, pp. 87-92.

Shervais J.W. The significance of subduction-related accretionary complexes in early Earth processes. In: (Reimold W.U., Gibson R.L., Eds.) Processes on the early Earth. Geol. Soc. of America, Special Paper, Vol. 405, 2006 pp. 173-192.

Shirey S.B., Kamber B.S., Whitehouse M.J., Mueller P.A., Basu A.R. A review of the isotopic and trace element evidence for mantle and crustal processes in the Hadean and Archean: Implications for the onset of plate tectonic subduction. In: (Condie K.C., Pease V., Eds.) When did plate tectonics pects of the Plate Tectonics Theory, Vol. 1 - Athens (Greece): Theophrastus Publications, 1990, pp. 17-37.

Sharkov E.V., Bogatikov O.A. Early stages of the tectonic and magmatic development of the Earth and Moon: similarities and differences. Petrology, Vol. 9, No. 2, 2001, pp. 97-118.

Sharp Z.D., Papike J.J., Durakiewicz T. The effect of thermal decarbonation on stable isotope compositions of carbonates. Amer. Mineralogist, Vol. 88, No. 1, 2003, pp. 87-92.

Shervais J.W. The significance of subduction-related accretionary complexes in early Earth processes. In: (Reimold W.U., Gibson R.L., Eds.) Processes on the early Earth. Geol. Soc. of America, Special Paper, Vol. 405, 2006 pp. 173-192.

Shirey S.B., Kamber B.S., Whitehouse M.J., Mueller P.A., Basu A.R. A review of the isotopic and trace element evidence for mantle and crustal processes in the Hadean and Archean: Implications for the onset of plate tectonic subduction. In: (Condie K.C., Pease V., Eds.) When did plate tectonics begin on planet Earth? Geol. Soc. of America, Special Paper, Vol. 440, 2008, pp. 1-29.

Silver P.G. Riding the Wilson Cycle; how the theory of plate tectonics continue to evolve. Geotimes, Vol. 52, No. 7, 2007, pp. 30-33.

Sizova E., Gerya T., Brown M., Perchuk L.L. Subduction styles in the Precambrian: Insight from numerical experiments. Lithos, Vol. 116, No. 3-4, 2010, pp. 209-229.

Sleep N.H. Martian plate tectonics. Journ. of Geophys. Research, Vol. 99, No. E3, 1994, pp. 5639-5655.

Sleep N.H. The Hadean-Archaean Environment. Cold Spring Harb. Perspect. in Biol., Vol. 2, No. 6, 2010, pp. 1-14.

Sleep N.H., Zahnle K., Neuhoff P.S. Initiation of clement surface conditions on the earliest Earth. Proc. Nat. Acad. Sci. USA, Vol. 98, No. 7, 2001, pp. 3666-3672.

Solomatov V.S. Initiation of subduction by small-scale convection. Journ. of Geophys. Research, Vol. 109, B01412, 2004, pp. 1-16.

Solomon S.C., Sleep N.H., Richardson R.M. On the forces driving plate tectonics: Inferences from absolute plate velocities and intraplate stress. Geoph. Journ. R. astr. Soc., Vol. 42, 1975, pp. 769-801.

Spooner E.T.C., Beckinsa R.D., Fyfe W.S., Smewing J.D. O ${ }^{18}$ Enriched ophiolitic metabasic rocks from E Liguria (Italy), Pindos (Greece), and Troodos (Cyprus). Contrib. to Mineralogy and Petrology, Vol. 47, No. 1, 1974, pp. 41-62.

Stacey F.D., Davis P.M. Physics of the Earth. Cambridge Univ. Press. Cambridge, UK, 2008, 513 p.

Stern R.J. Evidence from ophiolites, blueschists and ultrahighpressure metamorphic terranes that the modern episode of subduction tectonics began in Neoproterozoic time. Geology, Vol. 33, No. 7, 2005, pp. 557-560.

Stern R.J. When and how did plate tectonics begin? Theoretical and empirical considerations. Chinese Science Bull., Vol. 52, No. 5, 2007, pp. 578-591.

Stern R.J. Modern-style plate tectonics began in Neoproterozoic time: An alternative interpretation of Earth's tectonic history. GSA Special Papers, Vol. 440, 2008, pp. 265-280.

Stern R. J., Scholl D.W. Yin and yang of continental crust creation and destruction by plate tectonic processes. International Geology Review, Vol. 52, No. 1, 2010, pp. 1-31.

Stevenson D.J. Weakening under stress. Nature, Vol. 372, 1994, pp. 129-130.

Stewart J.A. Drifting continents and colliding paradigms: perspectives on the geoscience revolution. Indiana Univ. Press, USA, 1990, $304 \mathrm{p}$.

Sykes L.R. The seismicity and deep structure of island arcs. Journ. of Geophys. Research, Vol. 71, No. 12, 1966, pp. 2981-3006.

Tatsumi Y., Sato T., Kodaira Sh. Evolution of the Earth as an andesite planet: water, plate tectonics and delamination of 
begin on planet Earth? Geol. Soc. of America, Special Paper, Vol. 440, 2008, pp. 1-29.

Silver P.G. Riding the Wilson Cycle; how the theory of plate tectonics continue to evolve. Geotimes, Vol. 52, No. 7 , 2007, pp. 30-33.

Sizova E., Gerya T., Brown M., Perchuk L.L. Subduction styles in the Precambrian: Insight from numerical experiments. Lithos, Vol. 116, No. 3-4, 2010, pp. 209-229.

Sleep N.H. Martian plate tectonics. Journ. of Geophys. Research, Vol. 99, No. E3, 1994, pp. 5639-5655.

Sleep N.H. The Hadean-Archaean Environment. Cold Spring Harb. Perspect. in Biol., Vol. 2, No. 6, 2010, pp. 1-14.

Sleep N.H., Zahnle K., Neuhoff P.S. Initiation of clement surface conditions on the earliest Earth. Proc. Nat. Acad. Sci. USA, Vol. 98, No. 7, 2001, pp. 3666-3672.

Snider-Pellegrini A. Creation and its mysteries unveiled. Paris 1859 (in French).

Solomatov V.S. Initiation of subduction by small-scale convection. Journ. of Geophys. Research, Vol. 109, B01412, 2004, pp.1-16.

Solomon S.C., Sleep N.H., Richardson R.M. On the forces driving plate tectonics: Inferences from absolute plate velocities and intraplate stress. Geoph. Journ. R. astr. Soc., Vol. 42, 1975, pp. 769-801.

Spooner E.T.C., Beckinsa R.D., Fyfe W.S., Smewing J.D. O ${ }^{18}$ Enriched ophiolitic metabasic rocks from E Liguria (Italy), Pindos (Greece), and Troodos (Cyprus). Contrib. to Mineralogy and Petrology, Vol. 47, No. 1, 1974, pp. 41-62.

Stacey F.D., Davis P.M. Physics of the Earth. Cambridge Univ. Press. Cambridge, UK, 2008, 513 p.

Stern R.J. Evidence from ophiolites, blueschists and ultrahighpressure metamorphic terranes that the modern episode of subduction tectonics began in Neoproterozoic time. Geology, Vol. 33, No. 7, 2005, pp. 557-560.

Stern R.J. When and how did plate tectonics begin? Theoretical and empirical considerations. Chinese Science Bull., Vol. 52, No. 5, 2007, pp. 578-591.

Stern R.J. Modern-style plate tectonics began in Neoproterozoic time: An alternative interpretation of Earth's tectonic history. GSA Special Papers, Vol. 440, 2008, pp. 265-280.

Stern R. J., Scholl D.W. Yin and yang of continental crust creation and destruction by plate tectonic processes. International Geology Review, Vol. 52, No. 1, 2010, pp. 1-31.

Stevenson D.J. Weakening under stress. Nature, Vol. 372, 1994, pp. $129-130$.

Stewart J.A. Drifting continents and colliding paradigms: perspectives on the geoscience revolution. Indiana Univ. Press, USA, 1990, $304 \mathrm{p}$.

Stille H. Basic questions of comparative tectonics. Gehrüder Borntraeger, Berlin, 1924, 468 p. (in German).

Stille H. Introduction to the structure of America. Gehrüder Borntraeger, Berlin, 1940, 717 p. (in German).

Stille H. Geotectonic classification of the Earth's history. Academy of Sciences, under advising of W. de Gruyter. German Academy of Sciences in Berlin. Ser. of mathematics and science. Treatises, No. 3, 1944, 80 p. (in German).

Sykes L.R. The seismicity and deep structure of island arcs. Journ. of Geophys. Research, Vol. 71, No. 12, 1966, pp. 2981-3006.

Tatsumi Y., Sato T., Kodaira Sh. Evolution of the Earth as an andesite planet: water, plate tectonics and delamination of anti-continent. Earth, Planets and Space, Vol. 67, No. 91, 2015, pp. 1-10.

Taylor F.B. Bearing of the Tertiary mountain belt on the origin of the Earth's plan. Bulletin of the Geological Society of America, Vol. 21, 1910, pp.179-226.

Taylor F.B. Correlation of Tertiary mountain ranges in the different continents. The Geol. Soc. of America Bull., Vol. 41, 1930, pp. 431-473. anti-continent. Earth, Planets and Space, Vol. 67, No. 91, 2015, pp. $1-10$.

Taylor F.B. Bearing of the Tertiary mountain belt on the origin of the Earth's plan. Bulletin of the Geological Society of America, Vol. 21, 1910, pp. 179-226.

Taylor F.B. Correlation of Tertiary mountain ranges in the different continents. The Geol. Soc. of America Bull., Vol. 41, 1930, pp. 431-473.

Taylor S.R., McLennan S.M. Planetary crusts: their composition, origin and evolution. Cambridge Univ. Press. Cambridge, UK, 2009, $378 \mathrm{p}$.

Thomas H.S. The necessity for geological laws. Proceedings of the Oklahoma, Academy of Science for 1931, Vol. 12, 1932, pp. 66-71.

Turcotte D.L., Morein G., Roberts D., Malamud B.D. Catastrophic resurfacing and episodic subduction on Venus. Icarus, Vol. 139, 1999, pp. 49-54.

Turcotte D.L., Schubert G. Geodynamics. John Wiley and sons. N.Y., USA, 1982, $450 \mathrm{p}$.

Turcotte D.L., Schubert G. Geodynamics. Cambridge Univ. Press. Cambridge, NY, USA, 2002, 456 p.

Turner S., Rushmer T., Reagan M., Moyen J.-F. Heading down early on? Start of subduction on Earth. Geology, Vol. 42, No. 2, 2014, pp. 139-142.

van Andel T.H. Plate tectonics. Geology. Encyclopædia Britannica, Inc. 2015

Valley J.W., Cavosie A.J., Fu B., Peck W.H., Wilde S.A. Comment on "Heterogeneous Hadean hafnium: evidence of continental crust at 4.4 to 4.5 Ga". Science, Vol. 312, No. 5777, 2006, pp. 1139.

Valley J.W., Peck W.H., King E.M., Wilde S.A. A cool early Earth. Geology, 30, No. 4, 2002, pp. 351-354.

Verhoogen J., Turner F.J., Weiss L.E., Wahrhafting C., Fyfe W.S. The Earth. An introduction to physical geology. HoltRinehart, NY, USA, 1970,748 pp.

Von Humbolft A. Letter to Karl Ludwig Willdenow. Berlin, 1801.

Wessel P., Müller R.D. Plate tectonics, crust and lithosphere dynamics. In: (Watts A.B., Ed.) Treatise on Geophysics, Vol. 6, Elsevier B.V., 2009, pp. 49-98.

White D.A., Roeder D.H., Nelson Th.H., Crowell J.C. Subduction. Geol. Society of America Bulletin, Vol. 81, 1970, pp. 3431-3432.

Whitmeyer S.J., Fichter L.S., Pyle E.J. New directions in Wilson Cycle concepts: supercontinent and tectonic rock cycles. Geosphere, Vol. 3, No. 6, 2007, pp.511-526.

Wilde S.A., Valley J.W., Peck W.H., Graham C.M. Evidence from detrital zircons for the existence of continental crust and oceans on Earth 4.4 Gyr ago. Nature, Vol. 409, 2001, pp.175-178.

Wilson J.T. A new class of faults and their bearing on continental drift. Nature, Vol. 207, 1965, pp. 343-347.

Wilson J.T. Did the Atlantic close and then re-open? Nature, Vol. 211, No. 5050, 1966, pp. 676-681.

Wilson J.T. On the building and classification of mountains. Journ. of Geophysical Research, Vol. 95, B5, 1990, pp. 6611-6628.

Wilson M. Plate-moving mechanisms: constraints and controversies. Journ. of the Geological Society, London, Vol. 150, 1993, pp. 923-926.

Witze A. The start of the world as we know it. Nature, Vol. 442, 2006, pp. 128-131.

Zhao D., Matsuzawa T., Hasegawa A. Morphology of the subducting slab boundary in the northeastern Japan arc. Physics of the Earth and Plan. Interiors, Vol. 102, 1997, pp. 89-104.

Zhao G., Cawood P.A., Wilde S.A., Sun M. Review of global 2.1$1.8 \mathrm{Ga}$ orogens: implications for a pre-Rodinia supercontinent. Earth-Science Reviews, Vol. 59, No. 1-4, 2002, pp. 125-162.

Zhao G., Sun M., Wilde S.A., Li S.Z. A Paleo-Mesoproterozoic supercontinent: assembly, growth and breakup. EarthScience Reviews, Vol. 67, No. 1-2, 2004, pp. 91-123. 
Taylor S.R., McLennan S.M. Planetary crusts: their composition, origin and evolution. Cambridge Univ. Press. Cambridge, UK, 2009, $378 \mathrm{p}$.

Thomas H.S. The necessity for geological laws. Proceedings of the Oklahoma, Academy of Science for 1931, Vol. 12, 1932, pp. 66-71.

Turcotte D.L., Morein G., Roberts D., Malamud B.D. Catastrophic resurfacing and episodic subduction on Venus. Icarus, Vol. 139, 1999, pp. 49-54.

Turcotte D.L., Schubert G. Geodynamics. John Wiley and sons. N.Y., USA, 1982, $450 \mathrm{p}$.

Turcotte D.L., Schubert G. Geodynamics. Cambridge Univ. Press. Cambridge, NY, USA, 2002, 456 p.

Turner S., Rushmer T., Reagan M., Moyen J.-F. Heading down early on? Start of subduction on Earth. Geology, Vol. 42, No. 2, 2014, pp. 139-142.

van Andel T.H. Plate tectonics. Geology. Encyclopædia Britannica, Inc. 2015.

Valley J.W., Cavosie A.J., Fu B., Peck W.H., Wilde S.A. Comment on "Heterogeneous Hadean hafnium: evidence of continental crust at 4.4 to 4.5 Ga". Science, Vol. 312, No. 5777, 2006, pp. 1139.

Valley J.W., Peck W.H., King E.M., Wilde S.A. A cool early Earth. Geology, 30, No. 4, 2002, pp. 351-354.

Verhoogen J., Turner F.J., Weiss L.E., Wahrhafting C., Fyfe W.S. The Earth. An introduction to physical geology. HoltRinehart. NY, USA, 1970, 748 p.

Von Humbolft A. Letter to Karl Ludwig Willdenow. Berlin, 1801.

Wegener A.L. The origin of the continents. Geol. Rundschau, Vol. 3, No. 4, 1912, pp. 276-292 (in German).

Wegener A. The forming of the continents and oceans (4 ed.), Friedrich Vieweg \& Sohn Akt. Ges, Braunschweig, 1929, 252 p. (in German).

Wessel P., Müller R.D. Plate tectonics, crust and lithosphere dynamics. In: (Watts A.B., Ed.) Treatise on Geophysics, Vol. 6, Elsevier B.V., 2009, pp. 49-98.

White D.A., Roeder D.H., Nelson Th.H., Crowell J.C. Subduction. Geol. Society of America Bulletin, Vol. 81, 1970, pp. 3431-3432.

Whitmeyer S.J., Fichter L.S., Pyle E.J. New directions in Wilson Cycle concepts: supercontinent and tectonic rock cycles. Geosphere, Vol. 3, No. 6, 2007, pp. 511-526.

Wilde S.A., Valley J.W., Peck W.H., Graham C.M. Evidence from detrital zircons for the existence of continental crust and oceans on Earth 4.4 Gyr ago. Nature, Vol. 409, 2001, pp. $175-178$.

Wilson J.T. A new class of faults and their bearing on continental drift. Nature, Vol. 207, 1965, pp. 343-347.

Wilson J.T. Did the Atlantic close and then re-open? Nature, Vol. 211, No. 5050, 1966, pp. 676-681.

Wilson J.T. On the building and classification of mountains. Journ. of Geophysical Research, Vol. 95, B5, 1990, pp. 6611-6628.

Wilson M. Plate-moving mechanisms: constraints and controversies. Journ. of the Geological Society, London, Vol 150, 1993, pp. 923-926.

Witze A. The start of the world as we know it. Nature, Vol. 442, 2006, pp. 128-131.

Zhao D., Matsuzawa T., Hasegawa A. Morphology of the subducting slab boundary in the northeastern Japan arc. Physics of the Earth and Plan. Interiors, Vol. 102, 1997, pp. 89-104.

Zhao G., Cawood P.A., Wilde S.A., Sun M. Review of global 2.1-1.8 Ga orogens: implications for a pre-Rodinia supercontinent. Earth-Science Reviews, Vol. 59, No. 1-4, 2002 pp. 125-162.

Zhao G., Sun M., Wilde S.A., Li S.Z. A Paleo-Mesoproterozoic supercontinent: assembly, growth and breakup. EarthScience Reviews, Vol. 67, No. 1-2, 2004, pp. 91-123.
Ziegler P.A. Plate tectonics, plate moving mechanisms and rifting. Tectonophysics, 215, No. 1-2, 1992, pp. 9-34.

Ziegler P.A. Plate-moving mechanisms: their relative importance. William Smith Lecture 1992. Journ. of the Geological Society, London, Vol. 150, 1993, pp. 927-940.

Ampferer O. Über das Bewegungsbild, von Faltengebirgen. Jahrbuch der kaiserlich-koniglichen geologischen Reichsanstalt, Vol. 56, 1906, pp. 539-622.

Ampferer O., Hammer W. Geologischer Querschnitt durch die Ostalpen vom Allga'u zum Gardasee. Jahrb. Geol. Reichsanstalt, Vol. 61, Pts. 3-4, 1911, pp. 531-710

Holmes A. Radioaktivität und Geologie. Verh. Nat. Ges. Basel, Vol. 41, 1930, pp. 136-185.

Kober L. Der Bau der Erde. Gebrüder Borntraeger. Berlin, 1921, $324 \mathrm{p}$.

Schmeling H. Geodynamik. University of Frankfurt, 2004.

Schwinner R. Analogien im Bau der Ostalpen. Zentralblatt. Neues Jahrbuch für Mineralogie, Geologie und Paläontologie. Stuttgart, 1915, pp. 52-62.

Schwinner R. Vulkanismus und Gebirgsbildung. Ein Versuch. Zeitschrift für Vulkanologie, No. 5, 1919, pp. 175-230.

Stille H. Grundfragen der vergleichende Tektonik. Gebrüder Borntraeger. Berlin, 1924, 468 p.

Stille H. Einführung in den Bau Amerikas. Gebrüder Borntraeger. Berlin, 1940, $717 \mathrm{p}$

Stille H. Geotektonische Gliederung der Erdgeschichte. Akademie der Wissenschaften, in Kommission bei W. de Gruyter. Deutsche Akademie der Wissenschaften zu Berlin. Mathematisch-Naturwissenschaftliche Klasse. Abhandlungen, Jahrg. No. 3, 1944, 80 p.

Wegener A.L. Die Entstehung der Kontinente. Geol. Rundschau, Vol. 3, No. 4, 1912, pp. 276-292.

Wegener A. Die Entstehung der Kontinente und Ozeane (4 ed.). Friedrich Vieweg \& Sohn Akt. Ges., Braunschweig, 1929, $252 \mathrm{p}$.

Amstutz A. Sur 1'evolution des structures alpines. Archives Sci., Vol. 4, No. 5, 1951, pp. 323-329.

Bénard H. Les tourbillons cellulaires dans une nappe liquid. Revue Générale des Sciences pures et appliquées, Vol. 11, 1900, pp. 1261-1271 and 1309-1328.

Bénard H. Les tourbillons cellulaires dans une nappe liquide transportant de la chaleur par convection en régime permanent. Ann. Chem. Phys., Series 7, Vol. 23, 1901, pp. 62-144.

Snider-Pellegrini A. La Création et ses mystères dévoilés. Paris, 1859.

Абрамович А.А. (под ред.). Методы теоретической геологии. Недра. Ленинград, 1978, 335 с.

Алейников А.Л., Беликов В.Т., Эппельбаум Л.В. Некоторые физические основы геодинамики. Издательство Кедем. Тель-Авив, Израиль, 2001, 172 с.

Белоусов В.В. Основы геотектоники. Недра. Москва, 1975, $264 \mathrm{c}$.

Ивин А.А. Искусство правильно мыслить. Просвещение. Москва, 1986, 224 с.

Наймарк А.А. Полвека дискуссии фиксистов и неомобилистов: анализ реальности или гипотез, поиски истины или «удобной» теории? Вестник КРАУНЦ. Том 2, №. 8, 2006, с. 177-187.

Фролов В.Т. О научной геологии (статья 3). Вестник Московского государственного университета, Серия 4: Геология, No.1, 2002, с. 6-14.

Хаин В.Е. Общая геотектоника. Недра. Москва, 1973, 512 с.

Хаин В.Е. Тектоника континентов и океанов. Научный Мир. Москва, 2001, 606 с.

Хаин В.Е., Короновский Н.В. Планета Земля от ядра до ионосферы. КДУ. Москва, 2007, 244 с. 
Ziegler P.A. Plate tectonics, plate moving mechanisms and rifting. Tectonophysics, 215, No. 1-2, 1992, pp. 9-34.

Ziegler P.A. Plate-moving mechanisms: their relative importance. William Smith Lecture 1992. Journ. of the Geological Society, London, Vol. 150, 1993, pp. 927-940.
Хаин В.Е., Шейнман Ю.М. Сто лет учения о геосинклиналях. Советская Геология, №.11, 1960, с. 3-44.

Эппельбаум Л.В. Многомодельный подход к исследованию геофизических объектов. Депонировано в ВИНИТИ, Академия наук СССР, №. 7842-87, 1987, с. 1-10.

\title{
ТЕКТОНИКА ПЛИТ И ЭВОЛЮЦИЯ ЗЕМЛИ: КОНЦЕПТУАЛЬНЫЙ ОБЗОР
}

\author{
Пильчин А.Н. ${ }^{1}$, Лев Эппельбаум Л.В. ${ }^{2}$ \\ ${ }^{1}$ Universal Geoscience and Environment Consulting Company, Онтарио, Канада \\ M2M4B1, Канада, Онтарио, Виллоудале, Хилда ав., 205:Ipilchin@ gmail.com \\ ${ }^{2}$ Отделение Наук о Земле, Факультет точных наук, Тель-Авивский Университет \\ 6997801, Израиль, Тель-Авив, Рамат Авив: levap@tauеx.tau.ac.il \\ ${ }_{3}^{3}$ Азербайджанский государственный университет нефти и промыпленности, \\ AZ1010, Азербайджан, г.Баку, просп. Азадлыг 20
}

Резюме. На протяжении последних столетий предпринимались многочисленные попытки осознать закономерности тектоно-геодинамических процессов, происходящих на Земле. Хотя ни одна парадигма не дала исчерпывающих ответов на все вопросы, настоящий обзор призван познакомить читателей с современным состоянием развития тектонических представлений об эволюции Земли. Надо отметить, что эволюция ранней Земли характеризовалась рядом уникальных процессов, характеризующихся неконвенциональными параметрами. Однако физико-химико-геологические параметры большинства из них были в значительной степени утрачены (стерты) в ходе последующей эволюции Земли; некоторые процессы оставили лишь слабые следы своего существования и некоторые остаточные эффекты (особенно те, что имели место в катерхее и раннем-позднем архее). Среди таких процессов можно отметить планетарную аккрецию Земли, образование ряда уникальных горных комплексов, инициирование процесса тектоники плит, появление основных сил, движущих тектонику плит, значительное влияние тепловых параметров, роль избыточного давления в различных физико-геологических условиях, стратификацию земной коры и литосферы по плотности и ряд других термодинамических процессов. Почти все они остаются недостаточно исследованными ввиду значительной неопределенности в сроках и способах их эволюции, а также неоднозначности их вторичных показателей и тектоногеофизических характеристик. В то же время многие тектоногеодинамические процессы и параметры были и остаются взаимосвязанными, и одновременное изменение множества различных факторов играло существенную роль в их воздействии на геологическую среду. Некоторые из этих сложных вопросов обсуждаются в данной статье. Например, какова роль феномена тектоники плит и когда на Земле начался этот процесс? Особое внимание в обзоре уделено непростым методам анализа природы тектонических процессов, применяемым ученымигеологами на протяжении многих поколений. В проведенном обзоре также использовались некоторые физические параметры, полученные на других планетах Солнечной системы.

Ключевые слова: тектоника плит, основные движущие силы, термодинамические модели, роль плотности, модели глубинного строения, ранняя эволюиия Земли

\section{PLITOLOR TEKTONIKASI VO YERIN TOKAMÜLÜ: KONSEPTUAL İCMAL}

\author{
Pilçin A.N. ${ }^{1}$, Eppelbaum L.V. ${ }^{2}$ \\ ${ }^{1}$ Universal Geoelm Və Әtraf Mühit ÜZRə Konsaltinq şirkəti, Ontario, Kanada \\ M2M4B1, Kanada, Ontario, Villoudale, Xilda av., 205:Ipilchin@gmail.com \\ ${ }^{2}$ Yer Elmlari bölmasi, Daqiq elmlar faqültasi, Tel- Oviv Universiteti, \\ 6997801, Ramat Әviv, Tel-Әviv, Israel: levar@post.tau.ac.il \\ ${ }^{3}$ Azarbaycan Dövlat Neft va Sanaye Universiteti, \\ AZ1010, Azərbaycan, Bakı şəh., Azadlıq prosp. 20
}

Xülasə. Son yüzilliklər ərzində Yerdə baş verən tektonik-geodinamik proseslərin qanunauyğunluğunun dərk edilməsinə çoxsay11 cəhdlərlə təşəbbüs göstərilmişdir. Hərçənd heç bir paradiqma bütün məsələlərə tam cavab verməmişdir, bu icmal Yerin təkamülünə dair tektonik təsəvvürlərin inkişafının müasir vəziyyəti ilə oxucuları tanış etməyə çağırışdır. Qeyd etmək lazımdır ki, ilkin Yerin təkamülü qeyri-konvensional parametrlərlə səciyyələnən bir sira unikal proseslərlə xarakterizə edilir. Lakin onların əksəriyyətinin fiziki-kimyəvi-geoloji parametrləri Yerin sonraki təkamülünün gedişində mühüm dərəcədə itirilmişdir (silinmişdir); bəzi proseslər özlərinin mövcüdluğunun yalnız zəif izlərini və qalıq effektlərini (xüsusilə Katerxeydə və İlkin-Gec Arxeydə baş verənlər) saxlamışlar. Belə proseslər içərisində Yerin planetar akkresiyası, bir sıra dă̆ komplekslərinin əmələ gəlməsi, plitələr tektonikası prosesinin öyrənilməsinə təşəbbüs, plitələr tektonikasını hərəkətə gətirən əsas qüvvələrin təzahürü, istilik parametrlərinin mühüm təsiri, müxtəlif fiziki-geoloji şəraitdə artıq təzyiqin rolu, yer qabı̆̆ 1 və litosferin sıxlığa görə stratifikasiyası və bir sıra digər termodinamik prosesləri qeyd etmək olar. Onların, demək olar ki, hamısı təkamülünün müddətlərində və üsullarındakı mühüm qeyri-müəyyənliyə, həmçinin onların ikincidərəcəli göstəricilərinin və tektonik-geofiziki xarakteristikaların qeyri-birmənalılığına görə, kifayət dərəcədə tədqiq edilməmişdir. Eyni zamanda bir çox tektonik-geodinamik proseslər və parametrlər qarşılıqlı əlaqədə olmuşlar və olurlar, və çoxsaylı müxtəlif faktorların eyni vaxtda dəyişı1məsi onların geoloji mühitə təsirində mühüm rol oynamışdır. Bu mürəkkəb məsələlərdən bəziləri hazırki məqalədə müzakirə olunur. Məsələn, plitələr tektonikası fenomeninin rolu necədir və Yerdə bu proses nə vaxt başlamışdır? Bir çox nəsillər ərzində alim-geoloqlar tərəfindən tətbiq edilən tektonik proseslərin təbiətinin analizinin sadə olmayan metodlarına icmalda əsas diqqət yetirilmişdir. Aparılmış icmalda Günəş sisteminin digər planetlərində alınmış bəzi fiziki parametlərdən də istifadə edilmiş̧ir.

Açar sözlar: plitalar tektonikasi, asas harakatverici qüvvalar, termodinamik modellar, sıxlı̆̆ın rolu, darinlik quruluşunun modellori, ilkin Yerin təkamülü 